\title{
1 Iridium Profiles and Delivery across the Cretaceous/Paleogene
}

\section{Boundary}

3 Selen Esmeray-Senlet ${ }^{\mathrm{a}, \mathrm{b}}$, Kenneth G. Miller $^{\mathrm{a}}$, Robert M. Sherrell ${ }^{\mathrm{a}, \mathrm{c}}$, Turgay Senlet ${ }^{\mathrm{d}}$,

$5 \quad{ }^{a}$ Department of Earth and Planetary Sciences, Rutgers University, Piscataway, NJ, USA,

$6 \quad 08854$

$7 \quad{ }^{b}$ Currently at Chevron Energy Technology Company, 1500 Louisiana St., Houston, TX, 8 USA, 77002

$9{ }^{c}$ Department of Marine and Coastal Sciences, Rutgers University, New Brunswick, NJ, 10 USA, 08903

$11{ }^{d}$ Google Inc., 3300 N Interstate Hwy 35 Austin, TX, USA, 78722

$12{ }^{e}$ Division Geology, Department of Earth and Environmental Sciences, KU Leuven

13 University, Celestijnenlaan 200E, 3001, Leuven, Belgium

$14{ }^{f}$ Marine Palynology \& Paleoceanography, Department of Earth Sciences, Faculty of

15 Geosciences, Utrecht University, Laboratory of Palaeobotany and Palynology,

16 Budapestlaan 4, 3584CD, Utrecht, Netherlands.

17

18

19 Corresponding author's email: selenesmeray@gmail.com, selenesmeray@chevron.com 
21 We examined iridium (Ir) anomalies at the Cretaceous/Paleogene (K/Pg)

22 boundary in siliciclastic shallow marine cores of the New Jersey Coastal Plain, USA, that

23 were deposited at an intermediate distance $(\sim 2500 \mathrm{~km})$ from the Chicxulub, Mexico

24 crater. Although closely spaced and generally biostratigraphically complete, the cores

25 show heterogeneity in terms of preservation of the ejecta layers, maximum concentration

26 of Ir measured ( $0.1 \mathrm{ppb}-2.4 \mathrm{ppb})$, and total thickness of the Ir-enriched interval (11-

$27119 \mathrm{~cm})$. We analyzed the shape of the Ir profiles with a Lagrangian particle-tracking

28 model of sediment mixing. Fits between the mixing model and measured Ir profiles, as

29 well as visible burrows in the cores, show that the shape of the Ir profiles was determined

30 primarily by sediment mixing via bioturbation. In contrast, Tighe Park 1 and Bass River

31 cores show post-depositional remobilization of Ir by geochemical processes. There is a

32 strong inverse relationship between the maximum concentration of Ir measured and the

33 thickness of the sediments over which Ir is spread. We show that the depth-integrated Ir

34 inventory is similar in the majority of the cores, indicating that the total Ir delivery at

35 time of the K/Pg event was spatially homogenous over this region. Though delivered

36 through a near-instantaneous source, stratospheric dispersal, and settling, our study shows

37 that non-uniform Ir profiles develop due to changes in the regional delivery and post-

38 depositional modification by bioturbation and geochemical processes.

39 Keywords: K/Pg boundary, impact Iridium, Iridium inventory, advection-diffusion

40 model, bioturbation 


\section{$41 \quad 1.1$ Introduction}

42 The discovery of anomalously high abundance of iridium (Ir) and other platinum 43 group elements (PGEs) at the Cretaceous/Paleogene (K/Pg) boundary led to the

44 hypothesis that the Earth was impacted by an $~ 8-10 \mathrm{~km}$ diameter asteroid, causing severe 45 environmental disturbance (Alvarez et al., 1980; Smit and Hertogen, 1980). The impact 46 hypothesis was supported by the subsequent discovery of shocked minerals (Bohor et al., 47 1987), impact spherules, and Ni-rich spinels (Smit and Kyte, 1984). Discovery of the 48 buried Chicxulub crater, $\sim 180$ to $200 \mathrm{~km}$ in diameter in Yucatan Peninsula, Mexico 49 (Hildebrand et al., 1991) also substantiated that the source of Ir and other PGEs is 50 extraterrestrial.

51 An extraterrestrial source is not the only means of yielding high Ir concentrations

52 at the $\mathrm{K} / \mathrm{Pg}$ boundary. Deccan flood basalts in modern-day India spanning the $\mathrm{K} / \mathrm{Pg}$

53 boundary have been suggested as a source for the Ir anomalies at the boundary (Officer

54 and Drake, 1985). Emplacement of Deccan basalts took $~ 600$ kyr primarily during Chron

55 C29r (Courtillot et al., 1986). Previous studies have suggested that the main pulse began

$56 \sim 340 \mathrm{kyr}$ prior to the $\mathrm{K} / \mathrm{Pg}$ boundary (Robinson et al., 2009), and ended at the $\mathrm{K} / \mathrm{Pg}$

57 boundary (Chenet et al., 2007; Keller et al., 2008), though more recent studies suggest the

58 largest pulse began at about the time of the boundary (Renne et al., 2015) or $250 \mathrm{kyr}$

59 before the boundary (Schoene et al., 2015). The suggestion that the origin of anomalies in

60 Ir and other platinum group elements (PGEs) are volcanic rather than extraterrestrial has

61 been challenged by measurements of sedimentary PGE ratios, showing similarity to those

62 of meteorites rather than terrestrial basalts (Evans and Chai, 1997; Evans et al., 1993; 
63 Koeberl, 2002). In addition, Sawlowicz (1993) and Shukla et al. (2001) proposed that the

64 contribution of Deccan basalts was too small and local to explain the global inventory of

65 Ir at the $\mathrm{K} / \mathrm{Pg}$ boundary.

66 Iridium anomalies, mostly associated with ejecta layers (Smit, 1999; Schulte et

67 al., 2010), have been recorded in more than $85 \mathrm{~K} / \mathrm{Pg}$ boundary sites globally (Claeys et

68 al., 2002; Schulte et al., 2010). The global occurrence of an Ir anomaly suggests that dust

69 and vapor from the impacting bolide and target rock rich in high-PGE meteoritic material

70 were transported to the stratosphere creating a homogeneous cloud encircling the Earth.

71 Then, Ir-rich material settled down from the atmosphere on scales of months (Toon et al.,

72 1982) and slowly settled through the water column (Claeys et al., 2002).

73 Outside the Gulf of Mexico, i.e., in the intermediate and distal sites from the

74 Chicxulub crater, there is no correlation between the peak Ir concentration and distance

75 from the impact site (Claeys et al., 2002). The original Ir-rich deposits can be

76 redistributed due to remobilization by sedimentary processes including bioturbation and

77 geochemical remobilization that can account for the site to site differences in Ir

78 concentrations (Sawlowicz, 1993; Claeys et al., 2002), as well as the shape of the Ir

79 anomaly profiles (Hull et al., 2011). In some K/Pg boundary sites the Ir anomaly is

80 concentrated in a thin $(\sim 1 \mathrm{~cm})$ interval, whereas at other locations it spreads over as much

81 as several meters of section (Smit, 1999; Claeys et al., 2002). Even geographically close

82 sites show different maximum concentrations of Ir and/or different thicknesses over

83 which the Ir enrichment is spread.

84 The New Jersey Coastal Plain (NJCP) contains a record of the K/Pg extinction

85 (Olsson, 1960), Ir anomaly, and spherules in both outcrops and in cores (Olsson, 1987; 
86 Landman et al., 2007; Miller et al., 2010; Esmeray-Senlet et al., 2015; Vellekoop et al.,

87 2016). Shallow cores $(<25 \mathrm{~m})$ drilled adjacent to outcrops of the K/Pg boundary localities

88 (Buck Pit 1, Tighe Park 1, Search Farm 1, Meirs Farm 1, Inversand, and Fort Monmouth

89 3) and deeper cores drilled onshore by Ocean Drilling Program (ODP) 174AX (Ancora,

90 Double Trouble, and Bass River) provide important constraints on the impact-related

91 features across the K/Pg boundary (Fig. 1). Previously, a 6-cm-thick spherule layer

92 immediately above the $\mathrm{K} / \mathrm{Pg}$ boundary was reported at Bass River with reworked clay

93 clasts and an Ir peak of 2.4 ppb (Olsson et al., 1997). Landman et al. (2007) reported a

$94 \sim 0.5 \mathrm{ppb}$ Ir anomaly from an outcrop section from Tighe Park, Freehold, NJ below a 20-

$95 \mathrm{~cm}$ thick bed containing Cretaceous markers. Miller et al. (2010) documented Ir

96 anomalies at Buck Pit 1, Tighe Park 1, Search Farm 1, Meirs Farm 1, and Bass River to

97 investigate the stratigraphic relationship between the Ir anomalies and the extinction

98 level. Updip sites yield lower Ir anomaly peak concentration ( $0.5 \mathrm{ppb})$ compared to the

99 downdip Bass River site and each core shows a different shape of Ir profile, despite being

100 deposited in close proximity.

101 We conducted additional Ir measurements in the Ancora, Double Trouble,

102 Inversand, and Fort Monmouth 3 sites (Fig. 1) in order to quantify Ir concentrations and

103 investigate potential Ir mobility in the New Jersey sections. Here we address two main

104 questions combining new data with the previous results. First, how did vertical

105 redistribution of $\mathrm{Ir}$ by sedimentary processes like bioturbation or geochemical

106 remobilization affect the shape of Ir profiles in the NJCP cores, deposited in shallow

107 marine settings at intermediate distances $(\sim 2500 \mathrm{~km})$ from the Chicxulub crater? Second,

108 could the variations in peak Ir anomaly concentrations in NJCP cores, ranging from low 
109 to moderate, be attributed to bioturbation, geochemical remobilization, redeposition, or

110 simply concentrations of background values? We analyze the shape of Ir profiles by

111 modeling Ir anomalies under a range of mixing conditions with a Lagrangian advection-

112 diffusion sediment mixing model (Hull et al., 2011) and compare the mixing model

113 parameters with physical observations in the cores. In order to place these Ir profiles in a

114 biostratigraphic context, we combine published planktonic foraminiferal and organic-

115 walled dinoflagellate data with additional palynological analyses on Tighe Park 1, Buck

116 Pit 1, and Inversand. Finally, we evaluate the similarities and differences in depth-

117 integrated anomalies (total vertical accumulation) among the NJCP cores, and discuss the

118 relevance of this quantity relative to the more-frequently-used peak Ir concentrations.

\section{$119 \quad 1.2$ Analytical Techniques}

120 Concentrations of Ir were measured using Sector Field Inductively Coupled

121 Plasma Mass Spectrometry at the Institute of Marine and Coastal Sciences, Rutgers

122 University. Pre-concentration and isolation of Ir from the sediment samples was carried

123 out using a NiS fire-assay technique modified after Ravizza and Pyle (1997). In this

124 method, sediment samples were dried at $105^{\circ} \mathrm{C}$ overnight, and $\sim 1 \mathrm{~g}$ subsample was finely

125 ground and homogenized using an acid-cleaned agate mortar and pestle. The resulting

126 powder was then mixed with pure Ni powder and sublimed sulfur (2:1 mass ratio), borax

127 (2:1 ratio to sediment mass), and a ${ }^{191}$ Ir enriched isotope spike prepared in $6.2 \mathrm{~N} \mathrm{HCl}$ and

128 calibrated against an independent NIST-traceable certified ICP-MS primary Ir standard

129 solution (High-Purity Standards). This mixture is then heated to $1000^{\circ} \mathrm{C}$ in a muffle 
130 furnace for 75 minutes to allow fusion. After fusion and rapid cooling, the glassy sample

131 was broken to release a bead of NiS containing scavenged Ir. Beads are then dissolved in

$1326.2 \mathrm{~N} \mathrm{HCl}$ at $190-200^{\circ} \mathrm{C}$ on a hot plate until $\mathrm{H}_{2} \mathrm{~S}$ evolution stops, then are filtered

133 through cellulose $0.45 \mu \mathrm{m}$ filters (Millipore HATF) to remove small insoluble particles

134 containing much of the Ir. Filters are then digested in concentrated $\mathrm{HNO}_{3}$ in $15 \mathrm{~mL}$

135 screw-cap Teflon vial (Savillex). Quantification of Ir concentrations used the method of

136 isotope dilution, which provides accurate concentrations even if Ir recovery is low or

137 variable. Low procedural blanks (equivalent to $7 \mathrm{pg} / \mathrm{g}$ ) combined with high sensitivity

138 mass spectrometry provide a detection limit of $\sim 10 \mathrm{pg} / \mathrm{g}=0.01 \mathrm{ppb}$. This method yields

139 excellent procedural reproducibility (precision based on analysis of replicate solid

140 subsamples $\pm 5 \%, 2 \sigma$; Table 1) for even the lowest Ir concentrations $(40-100 \mathrm{pg} / \mathrm{g})$

141 found in background samples, allowing unambiguous determination of Ir anomalies. For

142 the lowest background concentrations determined, we conservatively estimate uncertainty

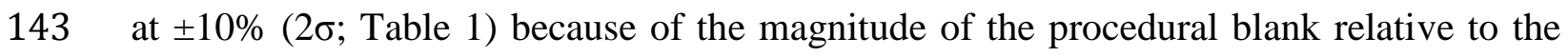

144 sample measurement, and propagated uncertainty in both.

145 For the foraminiferal and echinoid fecal pellet analyses core samples $(20 \mathrm{~g})$ were

146 disaggregated using Calgon solution (5.5 g of sodium metaphosphate per $4 \mathrm{~L}$ of water)

147 and washed with tap water through a $63 \mu \mathrm{m}$ sieve. After drying in an oven at $40^{\circ} \mathrm{C}$,

148 samples were sieved through $250,150,125$, and $63 \mu \mathrm{m}$ sieves and each size fraction

149 examined separately with a reflected-light microscope. Echinoid fecal pellets were

150 counted from the $63-250 \mathrm{~mm}$ size fraction using a micro-splitter, and number of fecal

151 pellets per gram of sample was determined. 
152 For palynological analysis $\sim 10$ gram of sample was crushed and oven dried at

$15360^{\circ} \mathrm{C}$. Samples were then treated with $10 \% \mathrm{HCl}$ to remove carbonate components and

$15440 \%$ HF to dissolve the siliceous components. The residue was sieved over nylon mesh

155 sieves of $250 \mu \mathrm{m}$ and $15 \mu \mathrm{m}$. From the residue of the $15-250 \mu \mathrm{m}$ fraction, quantitative

156 slides are prepared on well-mixed, representative fractions. All slides are stored in the

157 collection of the Division Geology, Department of Earth and Environmental Sciences,

158 KU Leuven, Belgium.

\section{$159 \quad 1.3$ Vertical Sediment Mixing and Mixing Model}

160 Bioturbation is the mixing of the upper part of the sediment column by burrowing

161 of benthic macrofauna, recycling the nutrients in the sediment mixed layer (Jumars et al.,

162 1990). The rate and extent of bioturbation have been investigated quantitatively using

163 geologically instantaneous markers like impact ejecta and volcanic ashes (Glass, 1969;

164 Ruddiman and Glover, 1972; Guinasso and Schink, 1975). Several techniques for

165 modeling the movement of sediment particles across the sediment-water interface and

166 into the permanent sedimentary record have been developed, as reviewed by Meysman

167 (2003). Traditional sediment mixing models are advection-diffusion models, where the

168 record of a sedimentary event is distributed within a mixed layer characterized by a

169 mixing coefficient (which can be modeled identically to a diffusion coefficient) and

170 advected by burrows into layers of sediments that are older than the event (Guinasso and

171 Schink, 1975). 
$172 \quad$ Hull et al. (2011) modified the one-dimensional Lagrangian particle-tracking 173 model with depth-dependent eddy diffusivity of Tanaka and Franks (2008) to model Ir 174 anomaly shapes across the K/Pg boundary. They used the mixing model to explain the 175 observed Ir anomaly shape at North Pacific DSDP Site 577B, Shatsky Rise (their Fig. 5).

176 The model fit the measured Ir profile at Hole 577B, showing a peak concentration of 5.6 177 ppb in an Ir anomaly that is spread over a $\sim 30$-cm-thick bioturbated interval, with an $\mathrm{r}^{2}$ of

1780.95 (Hull et al., 2011). The authors showed that the one-dimensional Lagrangian 179 particle-tracking model is successful in explaining Ir profile shapes, invoking only 180 physical sediment mixing. In this study, we use the mixing model of Hull et al. (2011) to 181 determine whether the anomaly profiles in this shallow water paleo-environment can be 182 similarly explained by bioturbation, and if so what mixing parameters best fit measured 183 iridium anomalies in the NJCP cores.

184 In the one-dimensional Lagrangian particle-tracking model of Hull et al. (2011), 185 the material is moved based on depth-dependent diffusivity with a non-deterministic 186 approach (Fig. 2). In the model, vertical diffusivity $\left(K_{v}\right)$ is modeled as a decreasing 187 hyperbolic tangent (tanh) function that generates a vertical diffusivity profile that is 188 continuously differentiable with depth (Ross and Sharples, 2004). Vertical diffusivity 189 decreases with depth, causing a well-mixed layer at the top underlain by increasingly

190 poorly mixed sediments. $K_{v}$ decreases with depth according to:

$$
K_{v}(z)=\frac{K_{0}}{2}\left[1-\tanh \left(\frac{z-z_{0}}{z_{\text {scale }}}\right)\right]
$$


192 where $z_{0}$ is the depth of the inflection point in the tanh profile, delineating the bottom of

193 the well-mixed layer of sediment; $z_{\text {scale }}$ is the e-folding scale for the tanh profile,

194 determining the depth over which mixing asymptotes to zero; and $K_{0}$ is the maximum

195 vertical diffusivity defining the upper limit of mixing in the tanh profile (not diffusivity at

196 the sediment-water interface) (Fig. 2).

197 Modeled iridium is moved vertically by vertical diffusivity as a Markov process,

198 where the depth $z_{t+\Delta t}$ of a particle at time $t+\Delta t$ is a function of the depth $\left(z_{t}\right)$ in the

199 previous time step (t):

$200 \quad z_{t+\Delta t}=z_{t}+\frac{\partial K_{v}\left(z_{t}\right)}{\partial z} \Delta t+R\left[\frac{2 K_{v}\left(z_{t}+\frac{1 \partial K v}{2 \partial z} \Delta t\right) \Delta t}{r}\right]^{1 / 2}+w_{S} \Delta t$

202 where $\mathrm{R}$ is a random process with a zero mean and a variance of $r$, where $r=1 / 3$. $\mathrm{R}$ is

203 selected from a uniform distribution ranging from -1 to 1 . Sedimentation rate $\left(w_{s}\right)$ causes

204 the sinking of sediment out of the mixed layer continuously. We took the time step $\Delta t$ as

2050.2 years to account for the low sedimentation rates in the NJCP cores.

206 We simulated Ir deposition by the introduction of particles into the model at the

207 sediment-water interface, with each particle representing an equal amount of Ir (Hull et

208 al., 2011). At the time of the event (K/Pg boundary), 100,000 particles were injected into

209 the model and mixed according to the different model parameterization. Particle numbers

210 were summed with $2 \mathrm{~cm}$ deep increments (di) to obtain Ir concentrations.

211 Earliest Paleocene sedimentation rates were calculated using planktonic

212 foraminiferal and/or dinocysts first and last appearances calibrated to the GTS2012 time

213 scale (Gradstein et al., 2012). Sedimentation rates calculated in the early Danian are 0.2 
$214 \mathrm{~cm} / \mathrm{kyr}$ at Bass River, Ancora, and Inversand and $0.3 \mathrm{~cm} / \mathrm{kyr}$ at Meirs Farm 1 and Double

215 Trouble. For Search Farm 1, and Tighe Park 1, we do not have enough biostratigraphic

216 information to calculate the sedimentation rates. Therefore, while running the model we

217 tried a combination of possible $w_{s}$ values $(0.1,0.2,0.3,0.4$, and $0.5 \mathrm{~cm} / \mathrm{kyr})$ with a range

218 of mixing parameters for each core. For all cores best model fit was obtained with

219 sedimentation rates of $0.2-0.3 \mathrm{~cm} / \mathrm{kyr}$. These slow sedimentation rates are a product of

220 low Maastrichtian to Danian terrigenous influx (Browning et al., 2008) and a collapse of

221 export pelagic productivity in the region in the Danian (D'Hondt, 2005; Esmeray-Senlet,

222 2015). Although food supply was limited in the early Danian on the NJCP (Esmeray-

223 Senlet, 2015) heavy bioturbation characterizes the boundary (e.g., Fig. 3 showing the

$224 \mathrm{~K} / \mathrm{Pg}$ boundary at Inversand, NJ).

225 The combination of mixing parameters $\mathrm{K}_{0}(0.75,1,1.5,5,10,100,250,1000$

$\left.226 \mathrm{~cm}^{2} / \mathrm{kyr}\right), \mathrm{z}_{0}(2,5,10,20,50,100,150 \mathrm{~cm})$, and $\mathrm{z}_{\text {scale }}(1.5,4,9.5 \mathrm{~cm})$ were simulated

227 over a period of 1500 years using MATLAB to get the best fit for the measured Ir

228 profiles. For each model the coefficient of determination $\left(\mathrm{r}^{2}\right)$ was calculated to determine

229 how well the model fit the measured Ir profiles. Five models with the highest $r^{2}$ are

230 shown in supplementary figures (Figs. S1, S2). The best combination of parameters was

231 selected and model simulations were repeated 50 times to take the average, as individual

232 model runs can vary due to the non-deterministic nature of the approach.

233 Ir concentrations measured in the NJCP cores are much lower that those of 234 European (e.g., Stevns Klint, Denmark; (Premovic et al., 2012) and Tunisian (e.g., El

235 Kef, Tunisia; (Ben Abdelkader et al., 1997) neritic sections. Although the model of Hull

236 et al. (2011) does not take background levels into account, we consider the background 
237 level of each core, since cores with low to moderate Ir anomalies yield low signal to

238 noise ratios. For each core, to find the background level we took the average of the

239 relatively constant values measured above and below the anomalies ( $\mathrm{n}=2$ to 16 samples

240 per core) excluding the data points of anomalously high Ir concentrations. The

241 background levels vary between $0.04 \mathrm{ppb}$ to $0.12 \mathrm{ppb}$. In the $\mathrm{r}^{2}$ calculation we excluded

242 data points less than or equal to the background level. We matched the lowest value of

243 the model to the calculated background level.

\section{$244 \quad 1.4$ Stratigraphy and Ir Anomalies}

245 The NJCP cores were deposited in shallow shelf settings with paleowater depths

246 of $20 \pm 5$ to $110 \pm 20 \mathrm{~m}$ during the Late Cretaceous - early Paleogene transition (Esmeray-

247 Senlet et al., 2015). Ancora, Double Trouble, and Bass River are downdip cores with

248 paleowater depths of $\sim 70,80,100 \mathrm{~m}$, respectively, allowing planktonic foraminiferal

249 habitats and thus biostratigraphy. All other cores are shallower with no or low

250 preservation of planktonic foraminifera. Fortunately, organic-walled dinoflagellate cysts

251 (dinocysts) are abundantly present in these records and allow confident biostratigraphic

252 age control across the $\mathrm{K} / \mathrm{Pg}$ boundary interval. In addition to biostratigraphy, we counted

253 echinoid fecal pellets that provide a distinct lowermost Danian stratigraphic horizon

254 useful for correlation (Figs. 4-6).

255 All cores were deposited at a distance $\sim 2500 \mathrm{~km}$ from the Chicxulub crater and 256 are considered intermediate sites based on their distance from the impact crater. 
257 Intermediate sites are described as having a distance of $\sim 1000$ to $\sim 5000 \mathrm{~km}$ from the

258 Chicxulub crater with a 2 - to $10-\mathrm{cm}$-thick spherule layer overlain by a $0.2-$ to $0.5-\mathrm{cm}$ -

259 thick layer having PGE enrichments, shocked minerals, rip-up clasts above the boundary

260 level from tsunamis, and Ni-rich spinels (Smit, 1999; Claeys et al., 2002; Schulte et al.,

261 2010). The NJCP cores show differential preservation of impact related features such as

262 spherule layer, clay clasts, and Ir enrichments (Figs. 4-6).

263 Bass River, the most complete and downdip core with a paleodepth of $\sim 100 \mathrm{~m}$,

264 shows a biostratigraphically complete upper Maastrichtian to lower Paleogene succession

265 (Fig. 4). The New Egypt Formation was assigned to Abathomphalus mayaroensis

266 planktonic foraminifera, Palynodinium grallator dinocyst, and Micula prinsii nannofossil

267 Zones, representing the uppermost Maastrichtian (Olsson et al., 1997; 2002).

268 Immediately above the Maastrichtian, there is a 6-cm-thick spherule layer with common

269 shocked quartz and feldspar grains and carbonate accretionary lapilli (Olsson et al., 1997;

270 2002; Yancey and Guillemette, 2008). Sediments above the spherule layer are assigned to

271 Danian planktonic foraminiferal Zones P0 (recognized in one sample, below the first

272 appearance datum of planktonic foraminiferal taxa Parvularugoglobigerina eugubina)

273 and $\mathrm{P} \alpha$, recognized by the appearance of Parvularugoglobigerina eugubina and the

274 dinoflagellate taxon Senoniasphaera inornata (Olsson et al., 1997). A 3-cm-thick layer

275 of white clay rip-up clasts containing uppermost Cretaceous foraminifera and dinocysts

276 overlies the spherule layer. There is a large Ir anomaly of $2.4 \mathrm{ppb}$ at the base of the

277 spherule bed and two modest Ir anomalies of 0.6 and $0.7 \mathrm{ppb}$ straddling the top of the

278 spherule bed associated with the clast layer. 
Ancora (Hole B) is biostratigraphically complete across the K/Pg boundary (Fig.

280 5), with the presence of planktonic foraminiferal Zones $\mathrm{P} 0$ and $\mathrm{P} \alpha$ in the earliest Danian

281 (Miller et al., 1999). It contains a 2.6-cm-thick spherule layer with grains of glauconite,

282 intermixed clay, and reworked foraminifera in planktonic foraminiferal Zone P1a (Miller

283 et al., 1999). The presence of glauconite grains and reworked foraminifera in this layer

284 was interpreted as an indication of the redeposition of the original microtektites and a

285 short hiatus between Zones P $\alpha$ and P1a (Miller et al., 1999). There is bioturbation in the

286 50-cm-thick sediments overlying the boundary. At Ancora there is a low Ir anomaly with

287 a maximum concentration of $0.13 \mathrm{ppb}$, spread over $\sim 107 \mathrm{~cm}$ across the K/Pg boundary.

288 At Double Trouble, bioturbated clayey glauconite sand of the Upper Cretaceous

289 Navesink Formation is overlain by the very dark green, clayey glauconite sand of the

290 Hornerstown Formation (Fig. 5). A $\sim 3.5 \mathrm{~cm}$-thick calcareous shell layer, assigned to

$291 \mathrm{P} 0 / \mathrm{P} 1$ a planktonic foraminiferal zone, is present $50 \mathrm{~cm}$ above the K/Pg boundary. At

292 Double Trouble, a low Ir anomaly of 0.16 ppb was measured straddling the boundary and

293 covering over $\sim 119 \mathrm{~cm}$.

294 At Search Farm 1 and Meirs Farm 1, basal Danian glauconite sands of the 295 Hornerstown Formation overlie clayey glauconite sand of the Upper Maastrichtian New 296 Egypt Formation (Fig. 6). The basal Danian is heavily burrowed at Meirs Farm 1, 297 whereas at Search Farm 1, the upper Maastrichtian also shows heavy bioturbation. 298 Although no distinct spherule layer exists, there is a 5-cm-thick white clay layer at Meirs 299 Farm 1 composed of siderite (Wahyudi, 2010). Although thought to be a clast (Miller et 300 al., 2010) studies of outcrops on adjacent creeks suggest that this is a layer and is likely 301 an alteration of the carbonate spherules and/or carbonate accretionary lapilli (Yancey and 
302 Guillemette, 2008). The clay at the K/Pg boundary is associated with a modest Ir 303 anomaly of $\sim 0.5 \mathrm{ppb}$ (Miller et al., 2010) that coincides with an increase in echinoid fecal 304 pellets. At Meirs Farm 1, the lowest occurrence of the lowermost Danian marker taxon 305 Senoniasphaera cf. inornata (Açıkalın et al., 2015; Vellekoop et al., 2014) occurs at 5 $306 \mathrm{~cm}$ above the white clay layer, followed by a succession of marker taxa such as

307 Senoniasphaera inornata s.s. and Damassadinium cf. californicum (Vellekoop et al., 308 2016). At Search Farm 1, Senoniasphaera cf. inornata was not encountered and the 309 lower, but not lowermost, marker taxa S. inornata and D. californicum occur almost 310 directly above the K-Pg boundary (Vellekoop et al., 2016).

311 The physical stratigraphy at Buck Pit 1 is slightly different from that in the other

312 cores (Fig. 5). At Buck Pit 1, indurated quartz sand of the uppermost Cretaceous Tinton 313 Formation is overlain by a $\sim 40-\mathrm{cm}$-thick clay unit. The clay unit consists of a basal red 314 clay and an overlying green clay. The Ir anomaly is spread over the clay unit with a peak 315 of $0.4 \mathrm{ppb}$ in the green clay. Although we did not find any impact spherules at Buck Pit 1

316 core, the adjacent $\mathrm{K} / \mathrm{Pg}$ outcrop, Campo Pit, has numerous spherules embedded in clay 317 clasts in the red and green clay (Esmeray-Senlet, 2015) associated with the lowest 318 occurrence of Senoniasphaera inornata, a dinocyst marker for the lower Danian (Miller 319 et al., 2010).

At Tighe Park 1, there is 20-cm-thick Pinna bed in the uppermost part of the

321 Cretaceous Tinton Formation, directly below the Paleogene Hornerstown Formation,

322 containing a diverse latest Cretaceous fauna including the ammonite Discoscaphites iris 323 and the bivalve Pinna laqueata in the adjacent outcrop (Landman et al., 2007). Above the 324 Pinna bed, the $\mathrm{K} / \mathrm{Pg}$ boundary is associated with the lowest occurrence of 
325 Damassadinium californicum and a peak of echinoid fecal pellets (Fig. 4). The Ir

326 anomaly of $\sim 0.5 \mathrm{ppb}$ occurs at the base of the Pinna bed, $20 \mathrm{~cm}$ below the $\mathrm{K} / \mathrm{Pg}$

327 boundary (Miller et al., 2010) confirming the relationship observed between Ir and the

328 Pinna bed in the adjacent outcrop in Agony Creek (Landman et al., 2007).

329 The Inversand Pit at Sewell is known for its well-preserved vertebrate fauna just

330 above the $\mathrm{K} / \mathrm{Pg}$ boundary. The bone bed in in the lowermost Hornerstown Formation, the

331 Main Fossiliferous Layer (MFL), contains the remains of Cretaceous microfossils and

332 macrofossils, including mosasaurs, fish, ammonites, and birds together with Paleogene

333 microfossils (Gallagher, 1993; 2002; Landman et al., 2004; 2007). An Ir concentration of

$3340.3 \mathrm{ppb}$ occurs in the middle of the 40 -cm-thick MFL that is $\sim 50 \mathrm{~cm}$ above the

335 Navesink/Hornerstown Formation contact (= K/Pg boundary in other cores) (Fig. 6). The

336 absence of an Ir anomaly at the Navesink/Hornerstown formation contact indicates a

337 short hiatus at the K/Pg boundary and reworking of Ir-rich sediments in the MFL that

338 consists of reworked Cretaceous and in situ Paleogene fauna.

339 The stratigraphy of Fort Monmouth 3 is similar to that of adjacent cores, having 340 an increase in echinoid fecal pellets across the lithological contact of New

341 Egypt/Hornerstown Formation contact (Fig. 6). However Ir concentrations across the 342 boundary show only background levels $(0.04-0.08 \mathrm{ppb})$. In the Fort Monmouth 3 core,

343 the lowermost Danian dinocyst marker taxon Senoniasphaera cf. inornata was not

344 encountered (Vellekoop et al., 2016). In this core, the lowest occurrences of S. inornata

345 s.s. and D. californicum occur directly at the base of the Hornerstown Fm., suggesting the 346 presence of a short hiatus. 


\subsection{Iridium Profile Shapes}

We applied the Lagrangian advection-diffusion mixing model to the NJCP cores,

349 where $\mathrm{Ir}$ is scattered across the $\mathrm{K} / \mathrm{Pg}$ boundary and bioturbation is visible (Ancora,

350 Double Trouble, Buck Pit 1, Search Farm 1, Meirs Farm 1). Mixing model fits to the

351 measured anomaly shapes are very good, with an $\mathrm{r}^{2}$ of $0.81-0.96$.

There is a strong correlation between mixing parameters obtained and physical

353 observations. In the cores in which Ir is dispersed over $\sim 107-119 \mathrm{~cm}$ (Double Trouble,

354 Ancora) $z_{0}$ (the bottom of the well-mixed layer) is $100-150 \mathrm{~cm}$; cores with Ir dispersion

355 of $\sim 30 \mathrm{~cm}$ (Buck Pit 1, Search Farm 1) show $z_{0}$ values of $20-50 \mathrm{~cm}$; and cores with Ir

356 dispersion of $\sim 10 \mathrm{~cm}$ (Meirs Farm 1) show $z_{0}$ values of $20 \mathrm{~cm}$ (Figs. 7-8). This indicates

357 that Ir dispersion across the K/Pg boundary can be explained by physical mixing of

358 sediments via bioturbation.

359 In the Tighe Park 1 and Bass River sections, the Ir peaks do not occur at the same

360 stratigraphic level as the biostratigraphic K/Pg boundary (Fig. 4). Miller et al. (2010)

361 discussed the relative position of the Ir anomaly and mass extinction level in the NJCP

362 cores and concluded that Ir is in situ, i.e. at the same level as the biostratigraphic $\mathrm{K} / \mathrm{Pg}$

363 boundary, in clay-rich sections, but remobilized geochemically in sandier sections like

364 Tighe Park 1 and Bass River. At Bass River, the highest Ir anomaly occurs $6 \mathrm{~cm}$ below

365 the appearance of Danian foraminifera and dinocysts, at the base of the spherule layer as

366 a narrow peak. Because the deposition of Ir takes place slowly as a result of atmospheric

367 fallout it should occur above the ballistic ejecta/spherule layer (Smit, 1999; Kring, 2007).

368 Thus, the Ir enrichment at the base of the spherule layer at Bass River is interpreted as 
369 resulting from geochemical remobilization of Ir down section by $6 \mathrm{~cm}$ (Miller et al.,

370 2010). Similarly, the Ir anomaly at Tighe Park 1 is a sharp peak at a redox boundary that

371 occurs $20 \mathrm{~cm}$ below the appearance of first Danian dinocysts at the base of the porous

372 Pinna layer where groundwater percolates from the outcrop (Miller et al., 2010). Both the

373 spherule layer at Bass River and the Pinna layer at Tighe Park 1 allowed percolation of Ir

374 that accumulated in a 2- to 3-cm-thick zones as distinct and narrow peaks above these

375 aquicludes (Miller et al., 2010) possibly due to differences in redox potential (Colodner et

376 al., 1992).

377 At Bass River, a secondary Ir enrichment of $\sim 0.7 \mathrm{ppb}$ straddles the top of the

378 spherule layer, where the original deposition of Ir should have occurred (Fig. 4). Also at

379 Tighe Park 1, 0.2 ppb Ir is dispersed in the heavily bioturbated clayey glauconite sand

380 of Hornerstown Formation just above the K/Pg boundary (Fig. 4). We applied the mixing

381 model to these intervals, on the assumption that they represent the redistribution of

382 particulate Ir by sediment mixing (Fig. 8). Model mixing parameters obtained for both

383 Bass River and Tighe Park 1 are in line with the physical observations. The best model fit

384 for Tighe Park 1 shows a $z_{0}$ of $100 \mathrm{~cm}$, where the dispersion of Ir is $\sim 30 \mathrm{~cm}$; whereas as 385 at Bass River with an Ir dispersion of $\sim 11 \mathrm{~cm} z_{0}$ is $10 \mathrm{~cm}$.

$386 \quad 1.6$ Integrated Iridium Anomalies and Total Iridium Delivery

The NJCP sites show different Ir profiles across the K/Pg boundary in terms of 388 maximum concentration of Ir measured, total thickness of the Ir-enriched interval, and 
389 background values of Ir (Table 1). However, there is a strong inverse relationship

390 between the maximum concentration of Ir measured and the thickness of the Ir diffusion

391 zone. The maximum Ir peak measured is $2.4 \mathrm{ppb}$ at Bass River and the anomaly is

392 concentrated within a 3-cm-thick layer (Fig. 4). Approximately $4 \mathrm{~cm}$ above this major

393 peak is a secondary enrichment of $\sim 0.7 \mathrm{ppb}$ that is $\sim 4 \mathrm{~cm}$ thick. Including both major and

394 secondary peaks, the total thickness of the Ir enrichment interval at Bass River is $11 \mathrm{~cm}$.

395 Meirs Farm 1, Search Farm 1, Buck Pit 1, and Tighe Park 1 show moderate Ir peaks of

$396 \sim 0.5 \mathrm{ppb}$ that are spread over $10-30 \mathrm{~cm}$ (Figs. 5, 6). At Ancora and Double Trouble,

397 where the thickness of the Ir-enriched interval reaches up to $\sim 119 \mathrm{~cm}$, there are much

398 lower maximum concentrations, 0.13 and $0.16 \mathrm{ppb}$, respectively (Fig. 5). This suggests

399 that Ir was diluted after the original time of deposition due to sedimentary processes of

400 bioturbation and/or geochemical remobilization, causing lower peak Ir anomalies.

401 We evaluate the integrated Ir signal over the thickness of the Ir-enriched interval 402 using the data above the background levels (Table 1Table 1). Using the trapezoidal rule, a 403 technique for approximating the definite integral, we calculated the area of the region that 404 is bounded by the Ir anomalies in each core. The area under the curve, i.e., the integrated 405 Ir signal indicates the total Ir delivery accumulation, independent of the distance over 406 which it was mixed vertically in the core.

407 Results show that the integrated Ir anomaly at Ancora, Double Trouble, Buck Pit 408 1, Tighe Park 1, and Bass River are very similar $\left(\sim 0.06 \mathrm{ppb}^{*} \mathrm{~m}\right)$, indicating that the total 409 Ir delivery to these cores were comparable (Table 1). Cores having higher Ir maxima, but 410 narrower peak vs. lower Ir maxima and diffused peaks show the same total Ir delivery 
411 indicating that the original Ir deposited was spread vertically across the $\mathrm{K} / \mathrm{Pg}$ boundary

412 by sedimentary and geochemical processes.

413 Search Farm 1, Meirs Farm 1, and Inversand show similar integrated Ir values to

414 each other, but lower than that of the other cores $\left(\sim 0.02 \mathrm{ppb}^{*} \mathrm{~m}\right)$. At Inversand, the Ir-rich

415 horizon is situated in the MFL, $50 \mathrm{~cm}$ above the $\mathrm{K} / \mathrm{Pg}$ boundary, and is interpreted as

416 reworked. Although the Ir peak is associated with the K/Pg boundary at Search Farm 1

417 and Meirs Farm 1, short hiatuses at the boundary are also possible, causing lower

418 integrated Ir anomalies in these two cores. However, dinocysts studies indicate that at

419 Meirs Farm 1, the dinocyst marker taxon Senoniasphaera cf. inornata is present

420 (Vellekoop et al., 2016), indicating that it is biostratigraphically complete, in contrast to

421 the Search Farm 1 and Fort Monmouth 3 cores.

422 White clasts containing Maastrichtian planktonic foraminifera and outer neritic

423 benthic foraminiferal assemblage were interpreted as rip-ups due to a tsunami that eroded

424 the outer continental shelf and upper slope after a slope failure triggered by earthquakes

425 generated by the Chicxulub impact (Norris et al., 2000; Olsson et al., 2002). This tsunami

426 was distinguished from the impact-generated mega-tsunami that reworked sediments in

427 the Gulf of Mexico, since Florida and Bahama platforms prevented tsunamis from

428 spreading from the Gulf of Mexico into the western North Atlantic (Norris et al., 2000).

429 This can also explain the heterogeneity of the preservation of the spherules on the NJCP

430 (Miller et al., 2010). 


\section{$431 \quad 1.7$ Conclusions}

432 The shape of the Ir profiles across the $\mathrm{K} / \mathrm{Pg}$ boundary and the maximum Ir 433 concentrations measured are highly variable among shallow shelf cores of NJCP, 434 although they were deposited geographically very close to each other. The shape of the Ir

435 profiles and the concentrations measured seem to appear determined primarily by 436 sedimentary and geochemical processes, especially bioturbation. Evidence supporting 437 sediment mixing are burrows visible in the cores and good fits between mixing model 438 and measured Ir profiles.

439 Using the Lagrangian advection-diffusion model (Hull et al., 2011), we were able 440 to show the extent of mixing effects on the Ir records quantitatively across the $\mathrm{K} / \mathrm{Pg}$ 441 boundary at 7 shallow-water cores in the NJCP. Modeling and fitting the model to the 442 measured iridium profiles showed that Ir anomaly shapes could generally be explained by 443 sediment mixing. Hull et al. (2011) showed that the model is successful in explaining Ir 444 profiles in a distal deep-sea site (Site 577B) with a less complicated mixing history. Our

445 modeling effort in shallow water cores at intermediate distance from the impact site 446 showed that the model is also applicable in sites with much more complicated mixing

447 histories. However, the mixing model should be applied carefully taking the background 448 values into account, where there is low signal-to-background ratio with low to moderate 449 Ir concentrations. Furthermore, for complex profiles, the model occasionally fails to fit 450 secondary peaks.

451 Our evaluation showed that the integrated Ir signal in the majority of cores is 452 indistinguishable in the NJCP, strongly suggesting that the total Ir delivery to this region 
453 was uniform at time of $\mathrm{K} / \mathrm{Pg}$ event. Although having received comparable mass of Ir, the

454 sites show different maximum concentrations of Ir that are inversely proportional to the

455 total thickness of the Ir-enriched interval. Interregional comparison show that variations

456 in Ir accumulations vary regionally and locally despite a near-instantaneous source,

457 stratospheric dispersal, and settling. Non-uniform Ir profiles develop due to changes in

458 the regional delivery and post-depositional modification by bioturbation and migration to

459 redox boundaries. This provides additional evidence of mixing dilution of Ir after the

460 original time of deposition. Additional elemental analysis is suggested as future work in

461 order to supply further evidence of Ir remobilization to redox boundaries.

462 It has been often thought that low Ir concentrations at the K/Pg boundary shows

463 the incompleteness of the boundary or might only be reflecting the accumulation of

464 cosmic dust due to low sedimentation rates (Sawlowicz, 1993). The findings of this

465 study, however, show that even modest Ir concentrations are a product of a single global

466 cause: the Chicxulub impact.

\section{$467 \quad 1.8$ Acknowledgements}

468 We thank DOSECC (Drilling, Observation and Sampling of the Earths Continental Crust)

469 for partially funding this study through their Research Grants in Scientific Drilling, S.

470 Tuorto and P. Field for helping apply the NiS fire-assay method, J.V. Browning for

471 assistance with the cores, R.K. Olsson for advice on planktonic foraminiferal

472 biostratigraphy, the USGS Eastern Geology and Paleoclimate Center drillers, and 
473 comments from two reviewers (C. Koeberl and anonymous). Supported by NSF grants

474 EAR-070778, OCE-0751757, OCE-1154379, and OCE14-63759 (Miller).

475 
477

478

479

480

481

482

483

484

485

486

487

488

489

490

491

492

493

494

495

496

497

498

499

500

501

502

503

504

505

506

507

508

509

Açıkalın, S., Vellekoop, J., Ocakoğlu, F., Yılmaz, İ.Ö., Smit, J., Ozkan Altiner, S., Goderis, S., Vonhof, H., Speijer, R., Voelders, L., Fornaciari, E., and Brinkhuis, H., 2015, Geochemical and palaeontological characterization of a new K-Pg Boundary locality from the Northern branch of the Neo-Tethys: Mudurnu-Göynük Basin, NW Turkey: Cretaceous Research, v. 52, p. 251-267.

Alvarez, L., Alvarez, W., Asaro, F., and Michel, H., 1980, Extraterrestrial cause for the Cretaceous-Tertiary extinction: Science, v. 208, p. 1095-1108.

Ben Abdelkader, O., Ben Salem, H., Donze, P., Maamouri, A., Méon, H., Robin, É., Rocchia, R., and Froget, L., 1997, The K/T stratotype section of El Kef (Tunisia): events and biotic turnovers: Geobios, v. 21, p. 235-245.

Bohor, B., Modreski, P., and Foord, E., 1987, Shocked quartz in the Cretaceous-Tertiary boundary clays: evidence for a global distribution: Science, v. 236, p. 705-709.

Browning, J.V., Miller, K.G., Sugarman, P.J., Kominz, M.A., McLaughlin, P.P., Jr, Kulpecz, A.A., and Feigenson, M.D., 2008, $100 \mathrm{Myr}$ record of sequences, sedimentary facies and sea level change from Ocean Drilling Program onshore coreholes, US Mid-Atlantic coastal plain: Basin Research, v. 20, p. 227-248, doi: 10.1111/j.1365-2117.2008.00360.x.

Chenet, A., Quidelleur, X., Fluteau, F., Courtillot, V., and Bajpai, S., 2007, 40K-40Ar dating of the Main Deccan large igneous province: Further evidence of KTB age and short duration: Earth and Planetary Science Letters, v. 263, p. 1-15.

Claeys, P., Kiessling, W., and Alvarez, W., 2002, Distribution of Chicxulub ejecta at the Cretaceous-Tertiary boundary (C. Koeberl \& K. G. MacLeod, Eds.): Catastrophic Events and Mass extinctions: Impacts and Beyond: Geological Society of America Special Paper, v. 356, p. 55-68.

Colodner, D., Boyle, E., Edmond, J., and Thomson, J., 1992, Post-depositional mobility of platinum, iridium and rhenium in marine sediments: Nature, v. 358, p. 402-404.

Courtillot, V., Besse, J., and Vandamme, D., 1986, Deccan flood basalts at the Cretaceous/Tertiary boundary?: Earth and Planetary Science Letters, v. 80, p. 361374.

D'Hondt, S., 2005, Consequences of the Cretaceous/Paleogene mass extinction for marine ecosystems: Annual Review of Ecology, Evolution, and Systematics, v. 36, p. 295-317.

Esmeray-Senlet, S., 2015, Biotic, paleoceanographic, and stratigraphic changes across the 
511 Esmeray-Senlet, S., Wright, J.D., Olsson, R.K., Miller, K.G., Browning, J.V., and Quan, 512 T.M., 2015, Evidence for reduced export productivity following the Cretaceous/Paleogene mass extinction: Paleoceanography, v. 30, doi:

515 Evans, N., and Chai, C., 1997, The distribution and geochemistry of platinum-group

Gallagher, W.B., 2002, Faunal changes across the Cretaceous-Tertiary (K-T) boundary in the Atlantic Coastal Plain of New Jersey: Restructuring the marine community after the K-T mass-extinction event: In: Koeberl, C., and MacLeod, K.G., eds., Catastrophic Events and Mass Extinctions: Impacts and Beyond: Geological Society of America, Special Paper, v. 356, p. 291-301.

Gallagher, W.B., 1993, The Cretaceous/Tertiary mass extinction event in the northern Atlantic Coastal Plain: The Mosasaur, v. 5, p. 75-155.

Glass, B.P., 1969, Reworking of deep-sea sediments as indicated by vertical dispersion of Australasian and Ivory Coast microtektite horizons: Earth and Planetary Science Letters, v. 6, p. 409-415.

Gradstein, F.M., Ogg, J.G., Schmitz, M., and Ogg, G., 2012, The Geologic Time Scale 2012 2-Volume Set: Elsevier BV, v. 1-2, p. 1176.

Guinasso, N.L., and Schink, D.R., 1975, Quantitative estimates of biological mixing rates in abyssal sediments: Journal of Geophysical Research, v. 80, p. 3032-3043.

Hildebrand, A., Penfield, G., Kring, D., Pilkington, M., and Camargo, Z., 1991, Chicxulub crater: a possible Cretaceous/Tertiary boundary impact crater on the Yucatan Peninsula, Mexico: Geology, v. 19, p. 867-871.

Hull, P.M., Franks, P.J.S., and Norris, R.D., 2011, Mechanisms and models of iridium anomaly shape across the Cretaceous-Paleogene boundary: Earth and Planetary Science Letters, v. 301, p. 98-106, doi: 10.1016/j.eps1.2010.10.031.

Jumars, P.A., Mayer, L.M., Deming, J.W., Baross, J.A., and Wheatcroft, R.A., 1990, Deep-sea deposit-feeding strategies suggested by environmental and feeding constraints: Philosophical Transactions of the Royal Society of London. Series A, Mathematical and Physical Sciences, v. 331, p. 85-101. 
Keller, G., Adatte, T., Gardin, S., Bartolini, A., and Bajpai, S., 2008, Main Deccan volcanism phase ends near the K-T boundary: Evidence from the Krishna-Godavari Basin, SE India: Earth and Planetary Science Letters, v. 268, p. 293-311, doi: 10.1016/j.epsl.2008.01.015.

Koeberl, C., 2002, Mineralogical and geochemical aspects of impact craters: Mineral Magazine, v. 66, p. 745-768, doi: 10.1180/0026461026650059.

Kring, D., 2007, The Chicxulub impact event and its environmental consequences at the Cretaceous-Tertiary boundary: Palaeogeography, Palaeoclimatology, Palaeoecology, v. 255 , p. $4-21$.

Landman, N., Johnson, R., and Edwards, L., 2004, Cephalopods from the Cretaceous/Tertiary boundary interval on the Atlantic Coastal Plain, with a description of the highest ammonite zones in North America. Part 1. Maryland and North Carolina: American Museum Novitates, v. 3454, p. 1-64.

559 Landman, N.H., Johnson, R.O., Garb, M.P., Edwards, L.E., and Kyte, F.T., 2007,

560

561

562

563

564

Meysman, F.J., Boudreau, B.P., and Middelburg, J.J., 2003, Relations between local, Cephalopods from the Cretaceous/Tertiary boundary interval on the Atlantic Coastal Plain, with a description of the highest ammonite zones in North America. Part III. Manasquan River Basin, Monmouth County, New Jersey: Bulletin of the American Museum of Natural History, v. 303, p. 1-122, doi: 10.1206/00030090(2007)303[1:CFTTBI]2.0.CO;2. nonlocal, discrete and continuous models of bioturbation: Journal of Marine Research, v. 61, p. 391-410.

Miller, K.G., Sherrell, R., Browning, J.V., Field, M., Gallagher, W., Olsson, R.K., Sugarman, P.J., Tuorto, S., and Wahyudi, H., 2010, Relationship between mass extinction and iridium across the Cretaceous-Paleogene boundary in New Jersey: Geology, v. 38, p. 867-870, doi: 10.1130/G31135.1.

Miller, K.G., Sugarman, P.J., Browning, J.V., Cramer, B.S., Olsson, R.K., de Romero, L., Aubry, M.-P., Pekar, S.F., Georgescu, M.D., Metzger, K.T., Monteverde, D.H., Skinner, E.S., Uptegrove, J., Mullikin, L.G., et al., 1999, Ancora Site (K. G. Miller, P. J. Sugarman, \& J. V. Browning, Eds.): Proceedings of the Ocean Drilling Program, Initial Reports, v. 174AX (supplement), p. 1-65.

580 Officer, C., and Drake, C., 1985, Terminal Cretaceous environmental events: Science, v. 581227, p. 1161-1167.

582 Olsson, R.K., 1987, Cretaceous stratigraphy of the Atlantic Coastal Plain, Atlantic 583 Highlands of New Jersey: Geological Society of America Centennial Field Guide- 
Northeastern Section, p. 87-90.

585 Olsson, R.K., 1960, Foraminifera of latest Cretaceous and earliest Tertiary age in the 586 New Jersey Coastal Plain: Journal of Paleontology, v. 34, p. 1-58.

587 Olsson, R.K., Miller, K.G., Browning, J.V., Habib, D., and Sugarman, P.J., 1997, Ejecta

588

589 layer at the Cretaceous-Tertiary boundary, Bass River, New Jersey (Ocean Drilling Program Leg 174AX): Geology, v. 25, p. 759-762.

590 Olsson, R.K., Miller, K.G., Browning, J.V., Wright, J.D., and Cramer, B.S., 2002,

591

592

593

594

595

596

597

598

599

600

601

602

603

604

605

606

607

608

609

610

611

612

613 Sequence stratigraphy and sea-level change across the Cretaceous-Tertiary boundary on the New Jersey passive margin: Geological Society of London, Special Publications, v. 356, p. $97-108$.

Premovic, P., I., Ilic, B., S., and Djordjevic, M., G., 2012, Iridium anomaly in the Cretaceous-Paleogene boundary at Højerup (Stevns Klint, Denmark) and Woodside Creek (New Zealand): The question of an enormous proportion of extraterrestrial component: Journal of the Serbian Chemical Society, v. 77, p. 247-255, doi: $10.2298 / \mathrm{JSC} 110404178 \mathrm{P}$.

Ravizza, G., and Pyle, D., 1997, PGE and Os isotopic analyses of single sample aliquots with NiS fire assay preconcentration: Chemical Geology, v. 141, p. 251-268.

Renne, P.R., Sprain, C.J., Richards, M.A., Self, S., Vanderkluysen, L., and Kanchan, P., 2015, State shift in Deccan volcanism at the Cretaceous-Paleogene boundary, possibly induced by impact: Science, v. 350, p. 76-78.

Robinson, N., Ravizza, G., Coccioni, R., Peucker-Ehrenbrink, B., and Norris, R.D., 2009, A high-resolution marine Os-187/Os-188 record for the late Maastrichtian: Distinguishing the chemical fingerprints of Deccan volcanism and the KP impact event: Earth and Planetary Science Letters, v. 281, p. 159-168, doi: 10.1016/j.epsl.2009.02.019.

Ross, O.N., and Sharples, J., 2004, Recipe for 1-D Lagrangian particle tracking models in space-varying diffusivity: Limnol. Oceanogr. Methods, v. 2, p. 289-302.

Ruddiman, W.F., and Glover, L.K., 1972, Vertical mixing of ice-rafted volcanic ash in North Atlantic sediments: Geological Society of America Bulletin, v. 83, p. 28172836.

617 Schoene, B., Samperton, K.M., Eddy, M.P., and Keller, G., 2015, U-Pb geochronology of 618 the Deccan Traps and relation to the end-Cretaceous mass extinction: Science, v. 619347, p. $182-184$. 
Schulte, P., Alegret, L., Arenillas, I., Arz, J.A., Barton, P., Bown, P., Bralower, T.J., Christeson, G., Claeys, P., and Cockell, C., 2010, The Chicxulub asteroid impact and mass extinction at the Cretaceous-Paleogene boundary: Science, v. 327, p. 12141218.

Shukla, P., Bhandari, N., Das, A., Shukla, A., and Ray, J., 2001, High iridium concentration of alkaline rocks of Deccan and implications to K/T boundary: Proc. Indian Acad. Sci. (Earth Planet Sci.), v. 110, p. 103-110.

Smit, J., 1999, The global stratigraphy of the Cretaceous-Tertiary boundary impact

Smit, J., and Hertogen, J., 1980, An extraterrestrial event at the Cretaceous-Tertiary ejecta: Annual Review of Earth and Planetary Sciences, v. 27, p. 75-113.

Smit, J., and Kyte, F.T., 1984, Siderophile-rich magnetic spheroids from the Cretaceous-

Tanaka, Y., and Franks, P.J.S., 2008, Vertical Distributions of Japanese Sardine (Sardinops Melanostictus) Eggs: Comparison of Observations and a Wind-Forced Lagrangian Mixing Model: Fisheries Oceanography, v. 17, p. 89-100, doi: 10.1111/j.1365-2419.2008.00466.x.

Toon, O.B., Pollack, J.B., Ackerman, T.P., Turco, R.P., McKay, C.P., and Liu, M.S., 1982, Evolution of an impact-generated dust cloud and its effects on the atmosphere: SPECIAL PAPERS-GEOLOGICAL SOCIETY OF AMERICA, v. 190, p. 187-200.

Vellekoop, J., Esmeray-Senlet, S., Miller, K.G., Browning, J.V., Sluijs, A., van de Schootbrugge, B., Sinninghe Damsté, J.S., and Brinkhuis, H., 2016, Evidence for Cretaceous-Paleogene boundary bolide "impact winter" conditions from New Jersey, USA: Geology,, p. G37961.1, doi: 10.1130/G37961.1.

Vellekoop, J., Sluijs, A., Smit, J., Schouten, S., Weijers, J.W.H., Sinninghe Damste, J.S., and Brinkhuis, H., 2014, Rapid short-term cooling following the Chicxulub impact at the Cretaceous-Paleogene boundary: Proceedings of the National Academy of Sciences, v. 111, p. 7537-7541, doi: 10.1073/pnas.1319253111.

Wahyudi, H., 2010, Lithofacies and depositional environment spanning the CretaceousPaleogene boundary on the New Jersey coastal plain: M.Sc. Thesis, Rutger University, New Brunswick.

Yancey, T.E., and Guillemette, R.N., 2008, Carbonate accretionary lapilli in distal deposits of the Chicxulub impact event: Geological Society of America Bulletin, v. 120, p. $1105-1118$. 


\section{$655 \quad 1.10$ Figure and Table Captions}

656 Fig. 1. Geological map of the New Jersey Coastal Plain showing coreholes that sampled 657 the K/Pg boundary. ODP Leg 174AX and ODP Leg 150X cores are shown as red circles. 658 Shallow cores are shown in blue circles.

660 Fig. 2. The Lagrangian sediment mixing model (Hull et al., 2011). Three mixing curves 661 highlight the effect of $\boldsymbol{z}_{\text {scale }}$ on depth-dependent diffusivity $\left(\boldsymbol{K}_{\boldsymbol{v}}\right)$. All curves are 662 parameterized with the same $\boldsymbol{z}_{\mathbf{0}}$, indicated on the depth axis, and the same $\boldsymbol{K}_{\mathbf{0}}$. Larger 663 values for $\boldsymbol{z}_{\text {scale }}$ (black lines) increase the depth range over which $\boldsymbol{K}_{\boldsymbol{v}}$ asymptotes to zero 664 relative to smaller $\boldsymbol{z}_{\text {scale }}$ values (dotted black and gray lines) (Hull et al., 2011, their Fig. $6651)$.

666

667 Fig. 3. Bioturbation at the K/Pg boundary in Inversand outcrop, New Jersey. 668

669 Fig. 4. Ir in parts per billion (ppb), fecal pellets in number/gram of sediment, core 670 photographs, lithology, formational assignments for Tighe Park 1 and Bass River 671 coreholes. Shocked minerals in Bass River are quartz and orthoclase feldspar (see Olsson 672 et al., 1997 for the details of the ejecta layer). Note the lowest occurrences of dinocyst 673 taxa at Tighe Park 1 (after Landman et al., 2007) and Bass River (Olsson et al., 1997). S.: 674 Senoniasphaera, D.: Damassadinium. Modified after (Miller et al., 2010).

676 Fig. 5. Ir in parts per billion ( $\mathrm{ppb}$ ), fecal pellets in number/gram of sediment, core 677 photographs, lithology, formational assignments for Ancora, Double Trouble, and Buck 678 Pit 1 coreholes. Planktonic foraminiferal biozones are indicated for Ancora and Double 679 Trouble. Note the lowest occurrences of dinocyst taxa S. inornata at adjacent at Buck Pit 

study). S.: Senoniasphaera, D.: Damassadinium.

682

683 Fig. 6. Ir in parts per billion ( $\mathrm{ppb}$ ), fecal pellets in number/gram of sediment, core 684 photographs, lithology, formational assignments for Search Farm 1, Meirs Farm 1, 685 Inversand, and Fort Monmouth 3 coreholes. Note the lowest occurrences of dinocyst taxa 686 at Search Farm 1, Meirs Farm 1, and Fort Monmouth 3 (Vellekoop et al., 2016). S.: 687 Senoniasphaera, D.: Damassadinium.

Fig. 7. Modeled Ir profiles for Ancora, Double Trouble, and Buck Pit 1 coreholes that provided best fits to the measured Ir profiles. Ir-modeled is plotted with blue crosses. Irmeasured is plotted with solid red circles; the open red circles show Ir samples that were not considered for the calculation of $r^{2}$. The mixing parameters and $r^{2}$ values obtained are: Ancora $\left(\mathrm{r}^{2}: 0.88, \boldsymbol{K}_{\mathbf{0}}: 1 \mathrm{~cm}^{2} / \mathrm{kyr}, \boldsymbol{z}_{\text {scale }}: 4 \mathrm{~cm}, \boldsymbol{z}_{\mathbf{0}}: 150 \mathrm{~cm}\right)$; Double Trouble $\left(\mathrm{r}^{2}: 0.85, \boldsymbol{K}_{\mathbf{0}}\right.$ : $\left.10 \mathrm{~cm}^{2} / \mathrm{kyr}, \boldsymbol{z}_{\text {scale }}: 9.5 \mathrm{~cm}, \boldsymbol{z}_{\mathbf{0}}: 100 \mathrm{~cm}\right)$; Buck Pit $1\left(\mathrm{r}^{2}: 0.80, \boldsymbol{K}_{\mathbf{0}}: 0.75 \mathrm{~cm}^{2} / \mathrm{kyr}, \boldsymbol{z}_{\text {scale }}: 9.5\right.$ $\left.695 \mathrm{~cm}, \boldsymbol{z}_{\mathbf{0}}: 50 \mathrm{~cm}\right)$. Sedimentation rates $\left(\boldsymbol{w}_{\boldsymbol{s}}\right)$ are $0.2 \mathrm{~cm} / \mathrm{kyr}$ at Ancora and Buck Pit 1 , and $6960.3 \mathrm{~cm} / \mathrm{kyr}$ at Double Trouble. Background values calculated are $0.04 \mathrm{ppb}$ for Ancora and Double Trouble, and $0.11 \mathrm{ppb}$ at Buck Pit 1. mbls: meters below land surface.

699 Fig. 8. Modeled Ir profiles for Search Farm 1, Meirs Farm 1, Tighe Park 1, and Bass 700 River coreholes that provided best fits to the measured Ir profiles. Ir-modeled is plotted 701 with blue crosses. Ir-measured is plotted with solid red circles; the open red circles show 702 Ir samples that were not considered for the calculation of $\mathrm{r}^{2}$. The mixing parameters and $703 \mathrm{r}^{2}$ values obtained are: Search Farm $1\left(\mathrm{r}^{2}: 96, \boldsymbol{K}_{\mathbf{0}}: 1000 \mathrm{~cm}^{2} / \mathrm{kyr}, \boldsymbol{z}_{\text {scale }}: 1.5 \mathrm{~cm}, \boldsymbol{z}_{\mathbf{0}}: 20\right.$ $704 \mathrm{~cm})$; Meirs Farm $1\left(\mathrm{r}^{2}: 0.82, \boldsymbol{K}_{\mathbf{0}}: 1000 \mathrm{~cm}^{2} / \mathrm{kyr}, \boldsymbol{z}_{\text {scale }}: 1.5 \mathrm{~cm}, \boldsymbol{z}_{\mathbf{0}}: 20 \mathrm{~cm}\right)$; Tighe Park 1 $705\left(\mathrm{r}^{2}: 0.95, \boldsymbol{K}_{\mathbf{0}}: 10 \mathrm{~cm}^{2} / \mathrm{kyr}, \boldsymbol{z}_{\text {scale }}: 4 \mathrm{~cm}, \boldsymbol{z}_{\mathbf{0}}: 100 \mathrm{~cm}\right)$; Bass River $\left(\mathrm{r}^{2}: 0.68, \boldsymbol{K}_{\mathbf{0}}: 100\right.$ $\left.706 \mathrm{~cm}^{2} / \mathrm{kyr}, \boldsymbol{z}_{\text {scale }}: 1.5 \mathrm{~cm}, \boldsymbol{z}_{\mathbf{0}}: 10 \mathrm{~cm}\right)$. Sedimentation rates $\left(\boldsymbol{w}_{\boldsymbol{s}}\right)$ are $0.2 \mathrm{~cm} / \mathrm{kyr}$ at Search 707 Farm 1 and Bass River, and $0.3 \mathrm{~cm} / \mathrm{yr}$ at Meirs Farm 1 and Tighe Park 1. Background 708 values calculated are $0.07 \mathrm{ppb}$ for Search Farm 1, $0.10 \mathrm{ppb}$ for Meirs Farm 1, $0.11 \mathrm{ppb}$ 
709 for Bass River, and 0.12 ppb for Tighe Park 1. mbls: meters below land surface. Note that

710 depth of Bass River is shown in cm above/below the K/Pg boundary.

711

712 Table 1. Table showing the maximum and minimum concentration of $\mathrm{Ir}$ measured in

713 each core, the total thickness of the Ir-enriched interval, average background values, and

714 the integrated Ir signal calculated. Uncertainties for the maximum and minimum values

715 are defined as explained in the text, and uncertainties for the average background values

716 represent the standard deviation of background samples. These background

717 concentrations were calculated for each core individually, by taking the average of the

718 relatively constant values measured above and below the anomalies, excluding the data

719 points of anomalously high Ir concentrations.

720

721

722

723

724

725

726

727

728

729

730

731

732 
733

734 


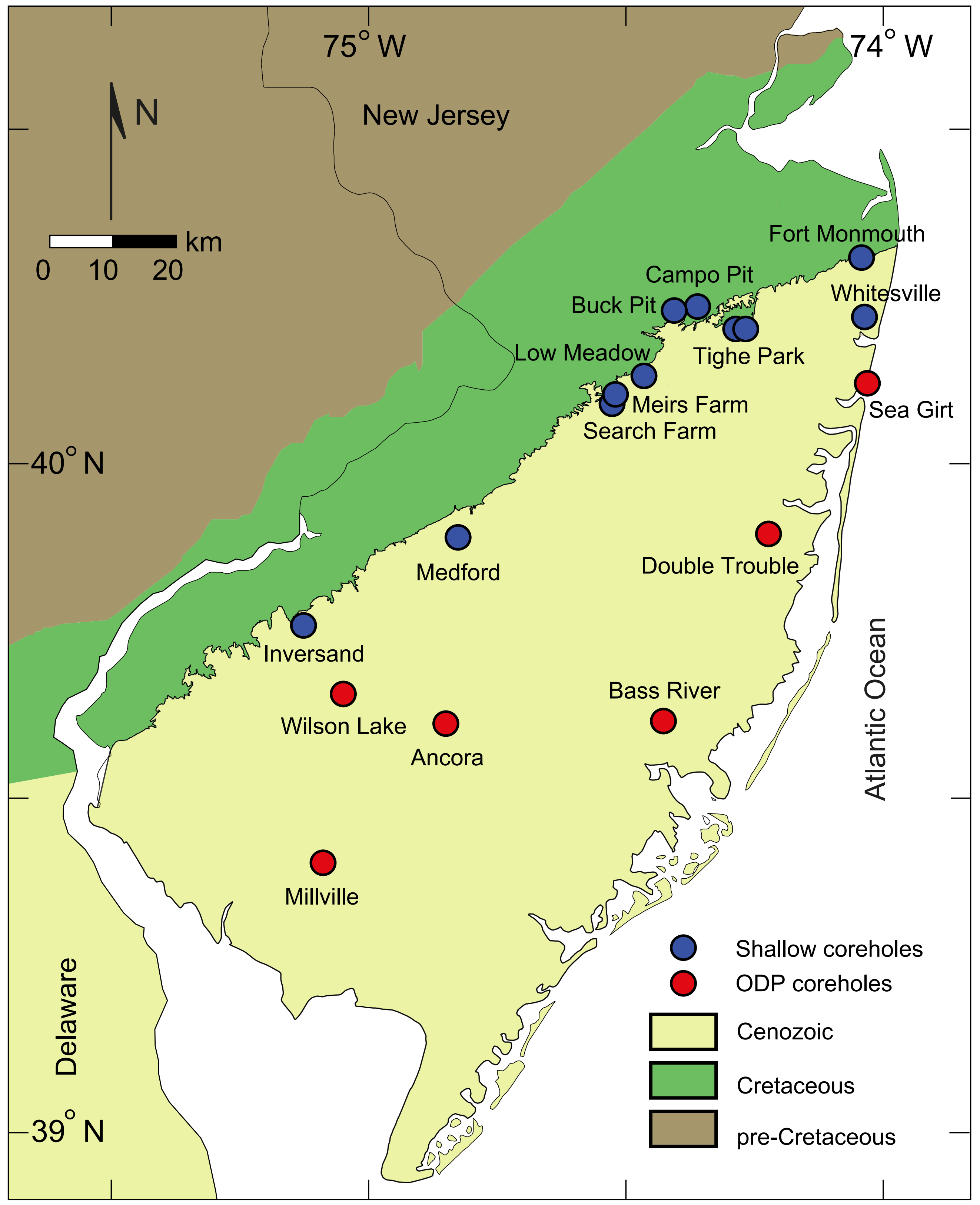




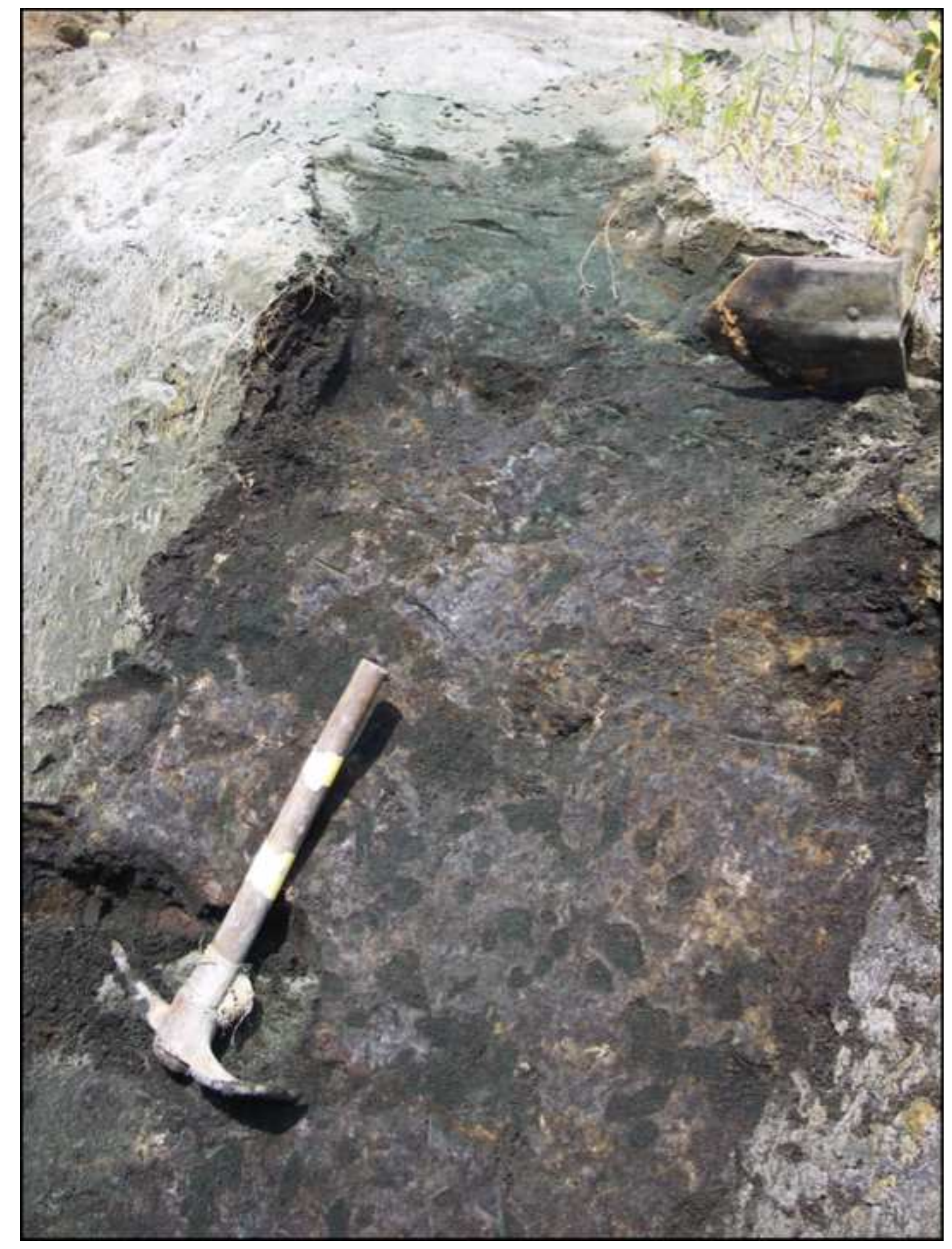

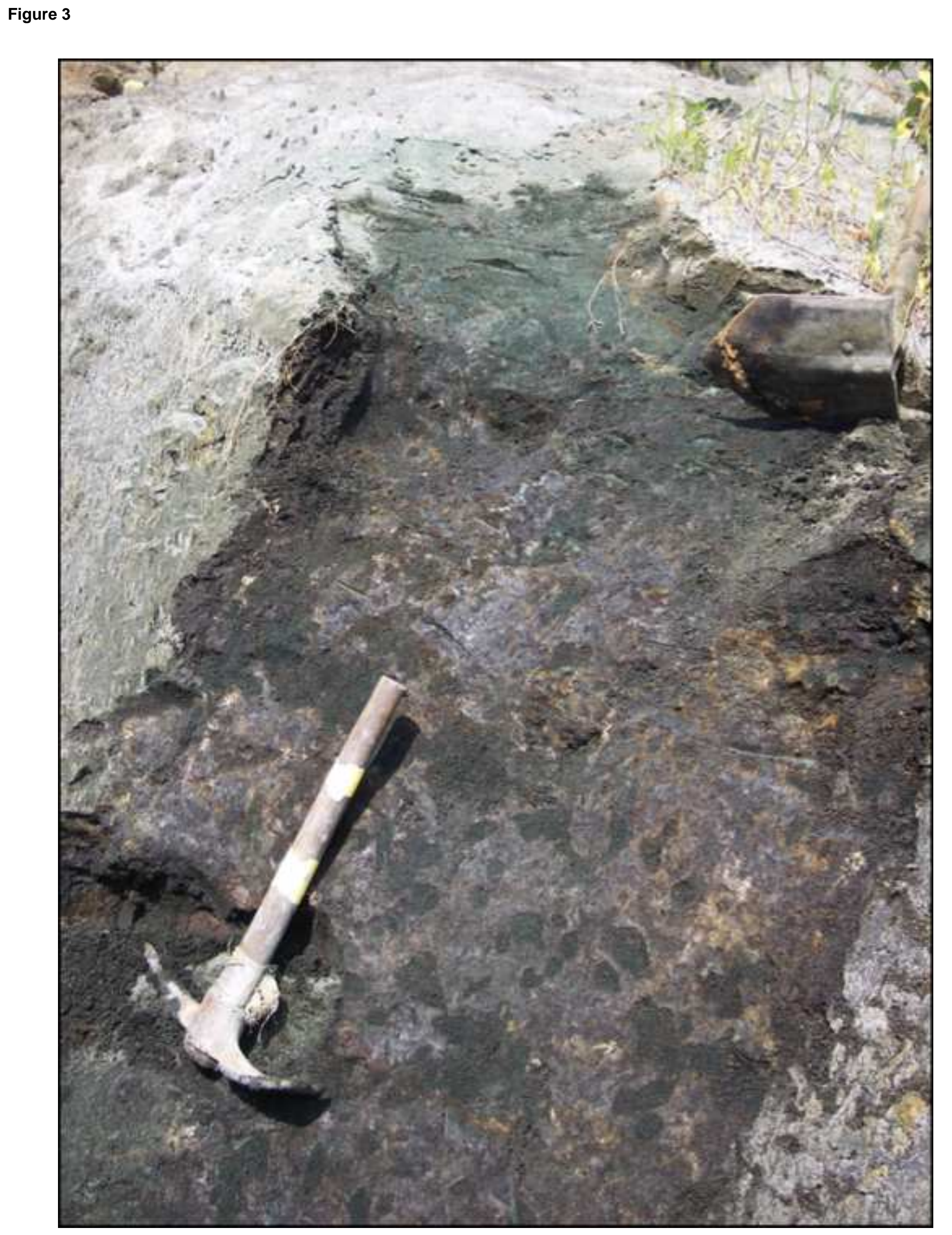

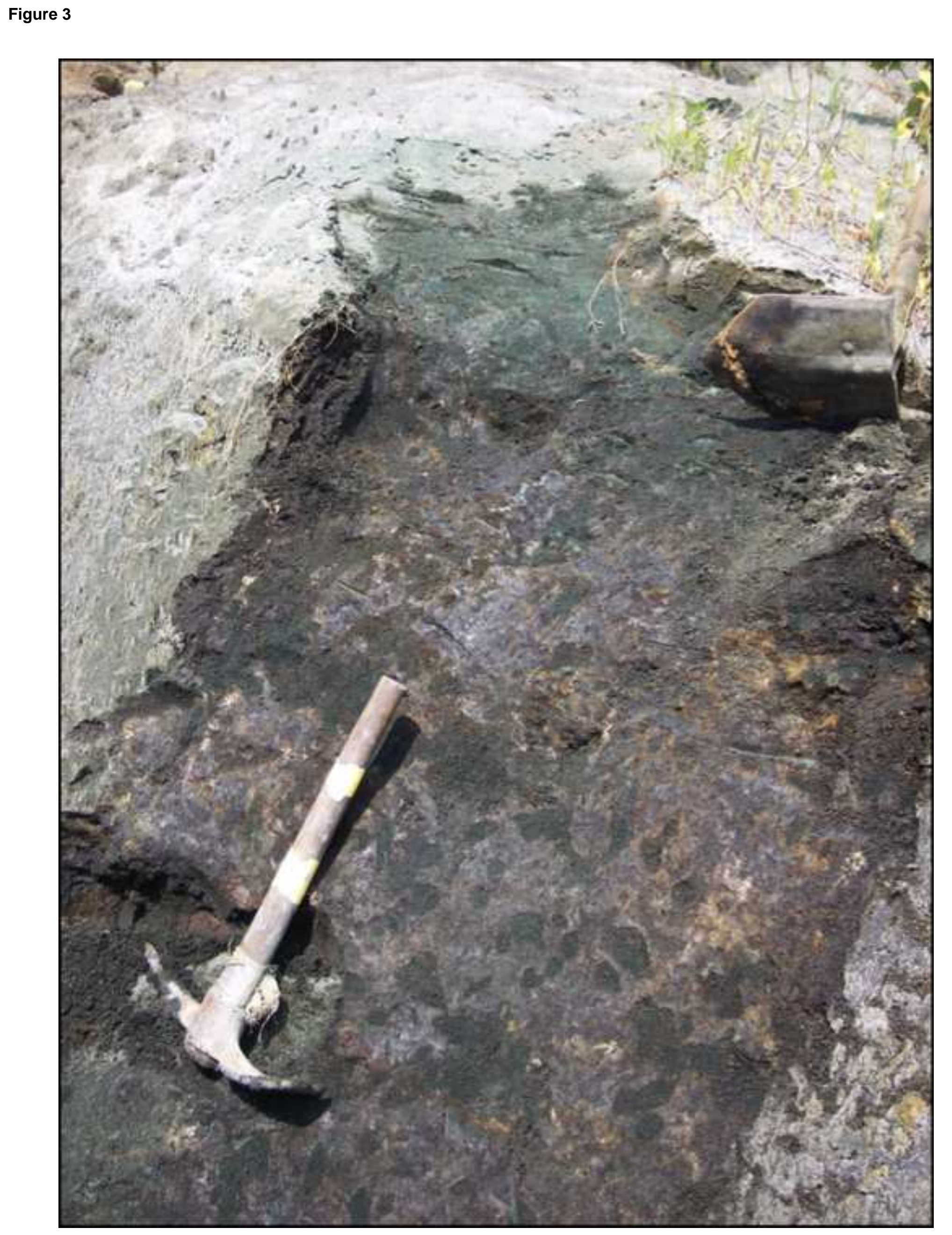

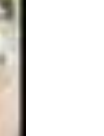

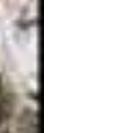

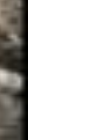$$
\text { . }
$$

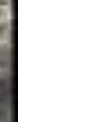

.

$$
\text { . }
$$

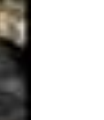

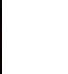

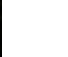

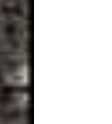

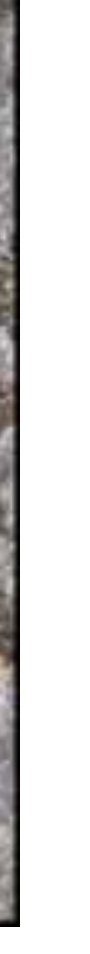



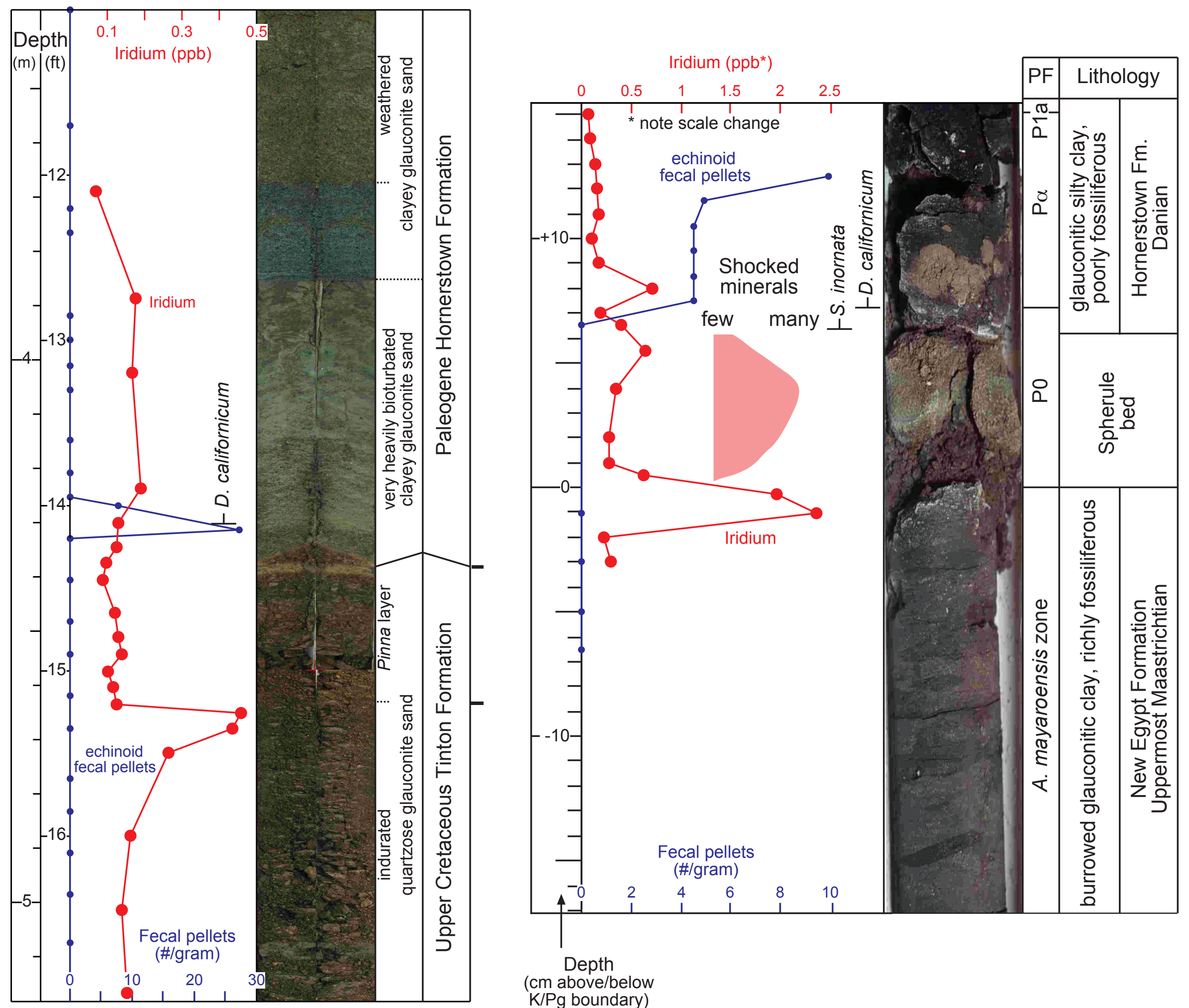

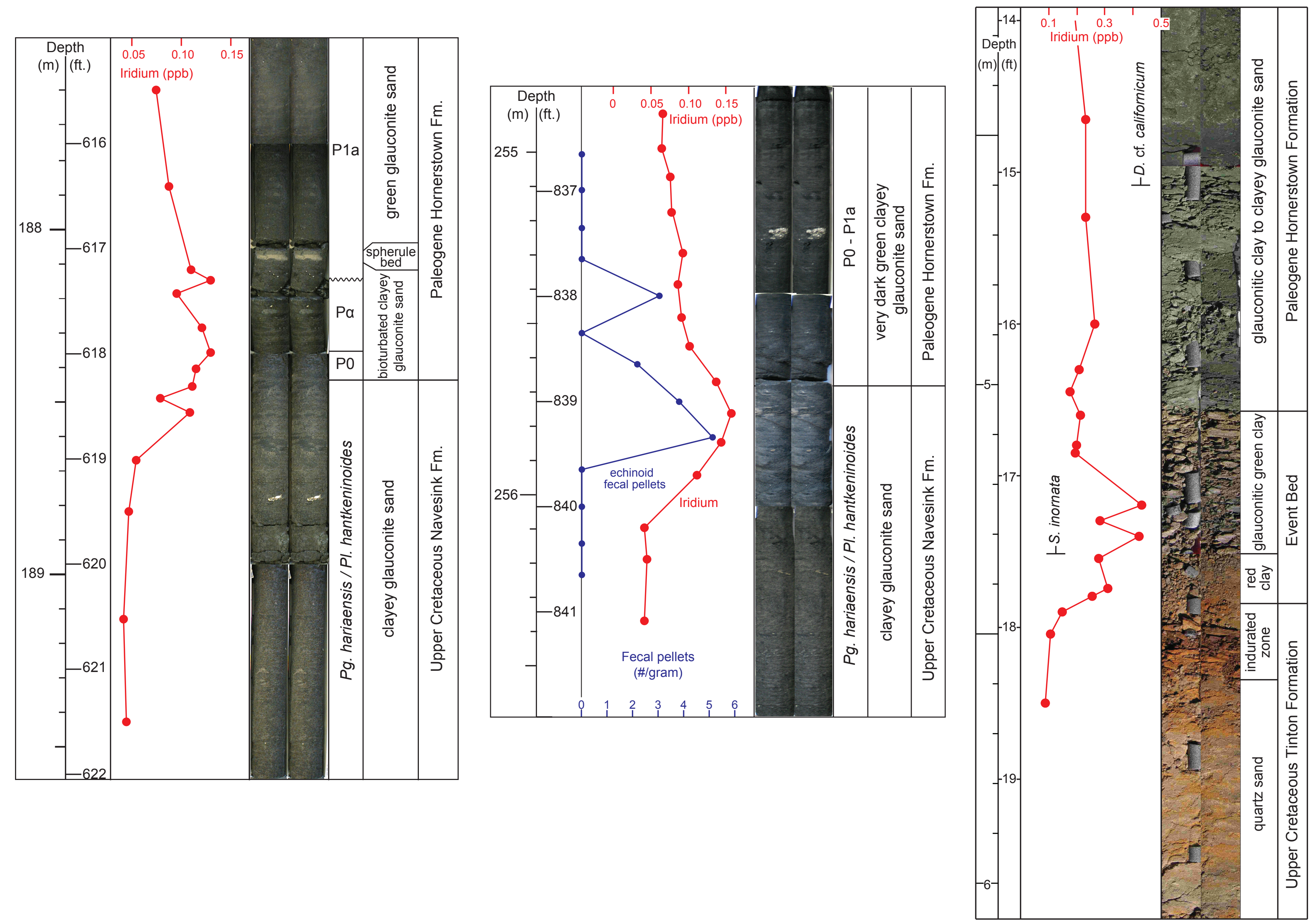

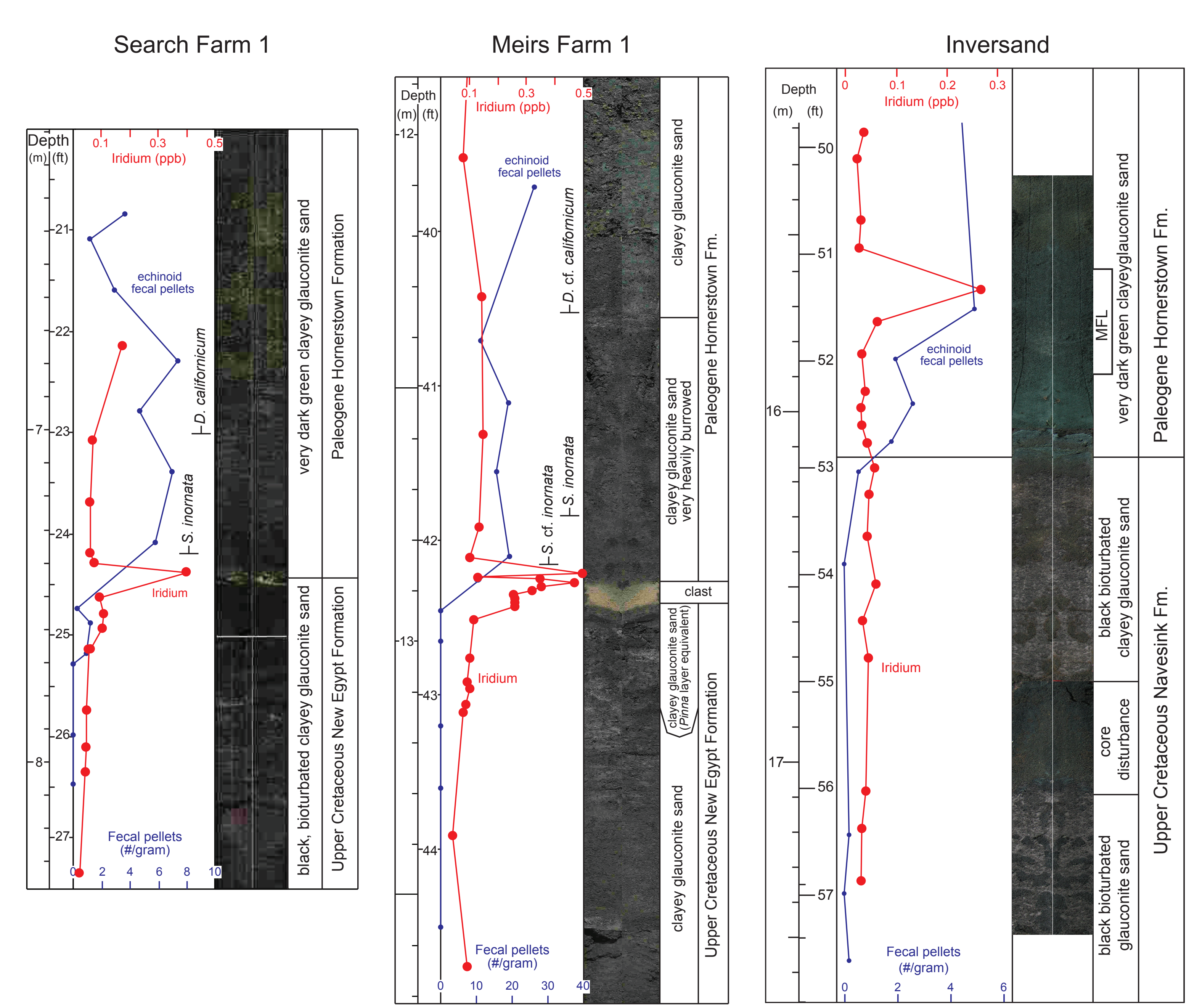

Fort Monmouth 3

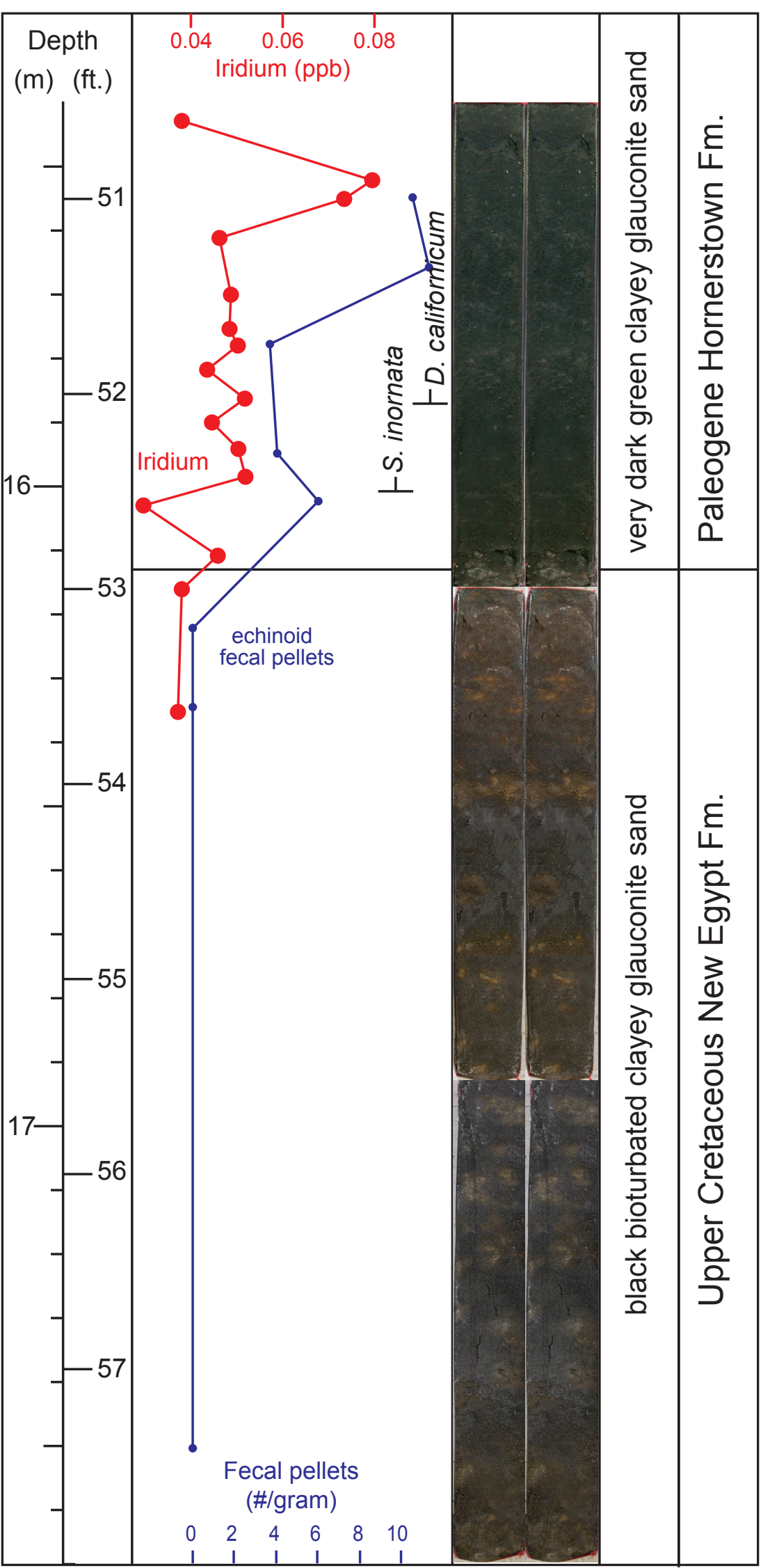




\section{Ancora}

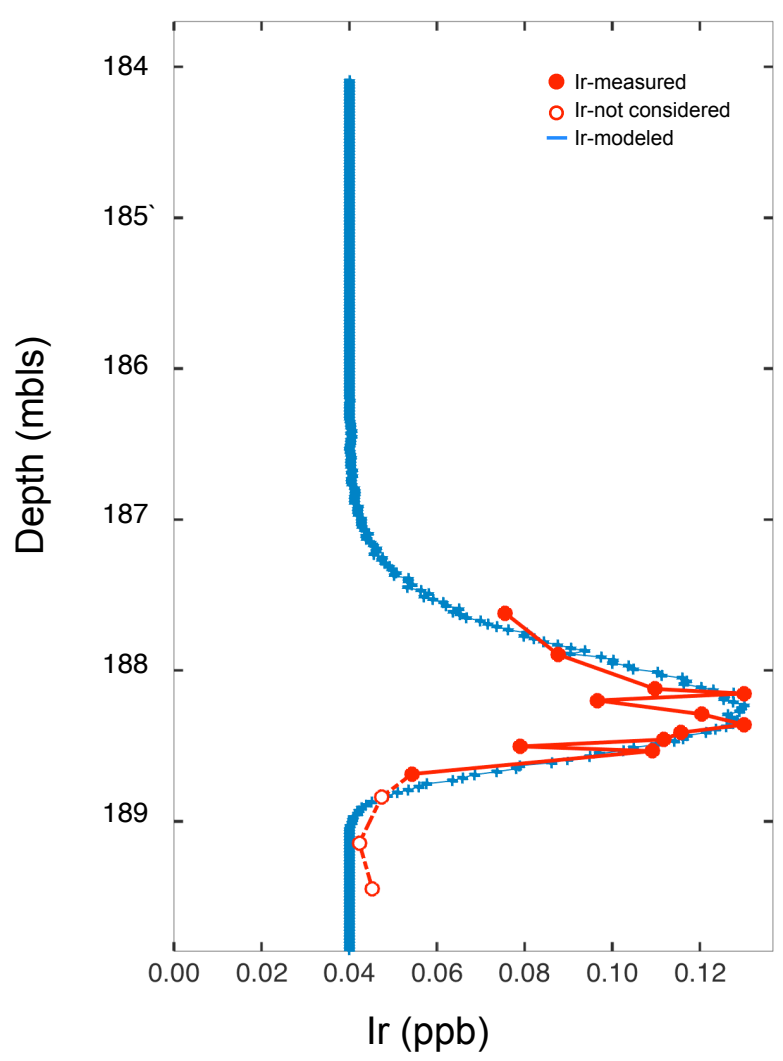

Double Trouble

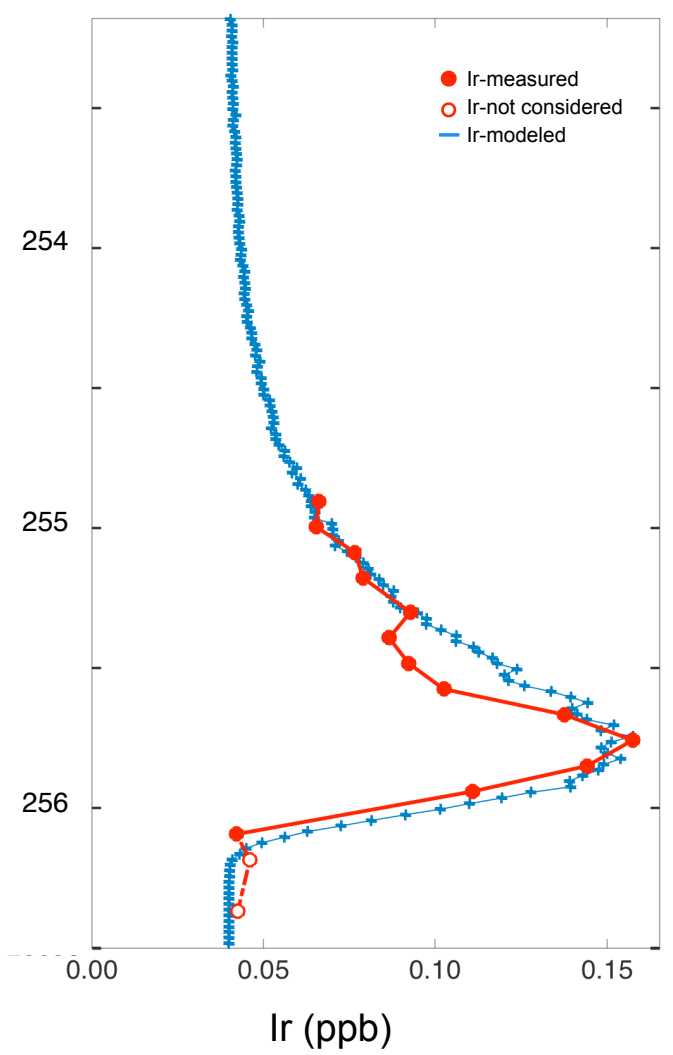

\section{Buck Pit 1}

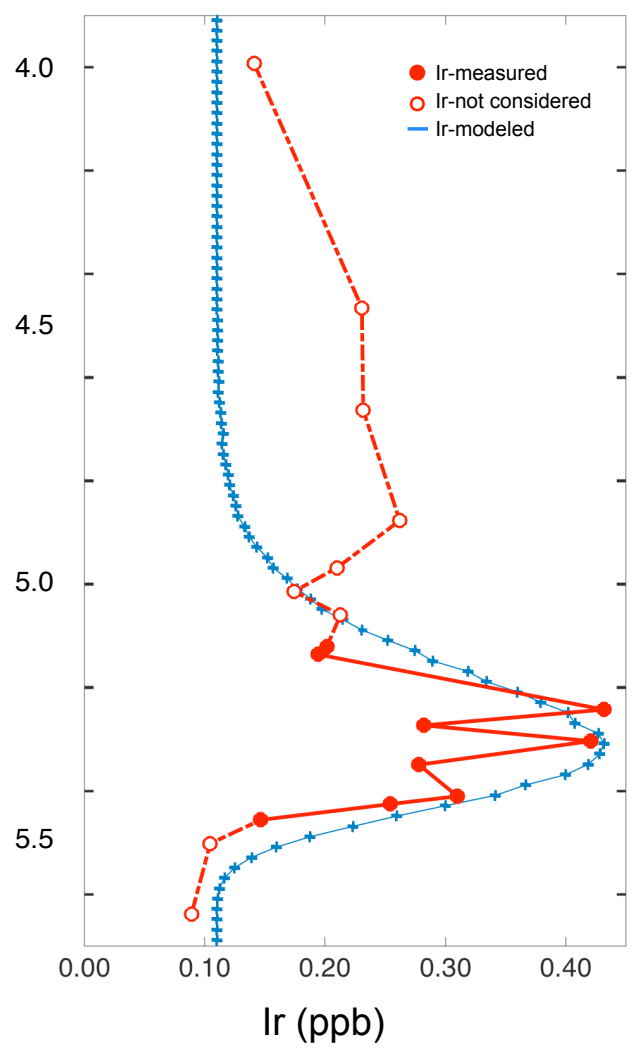


Search Farm 1

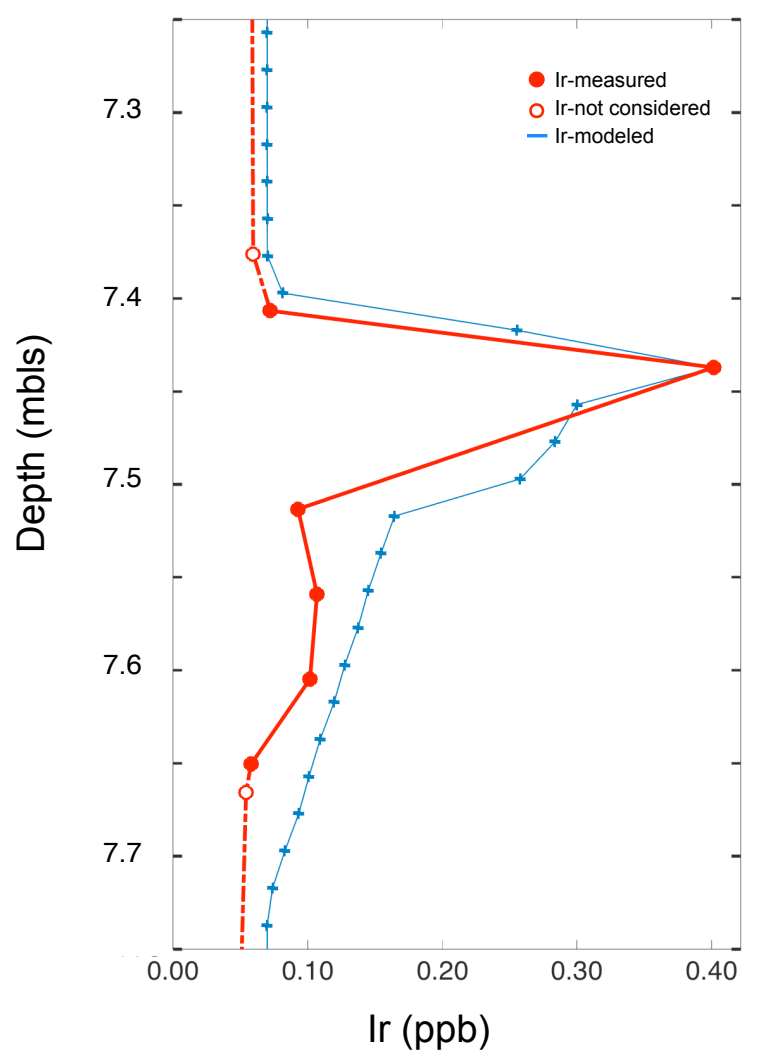

Meirs Farm 1

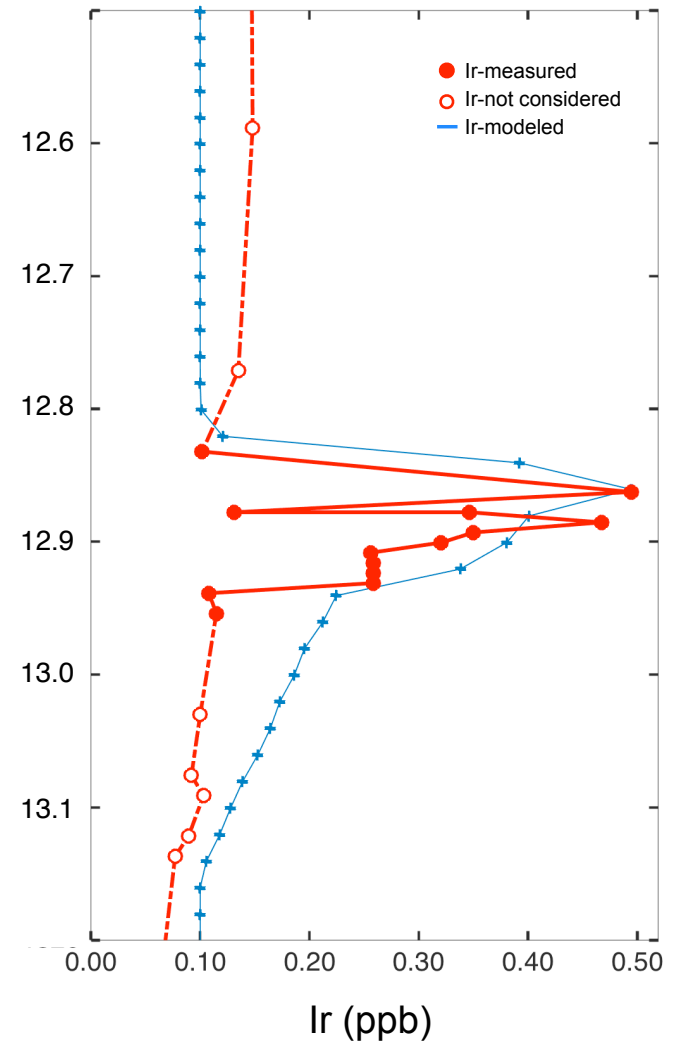

Tighe Park 1

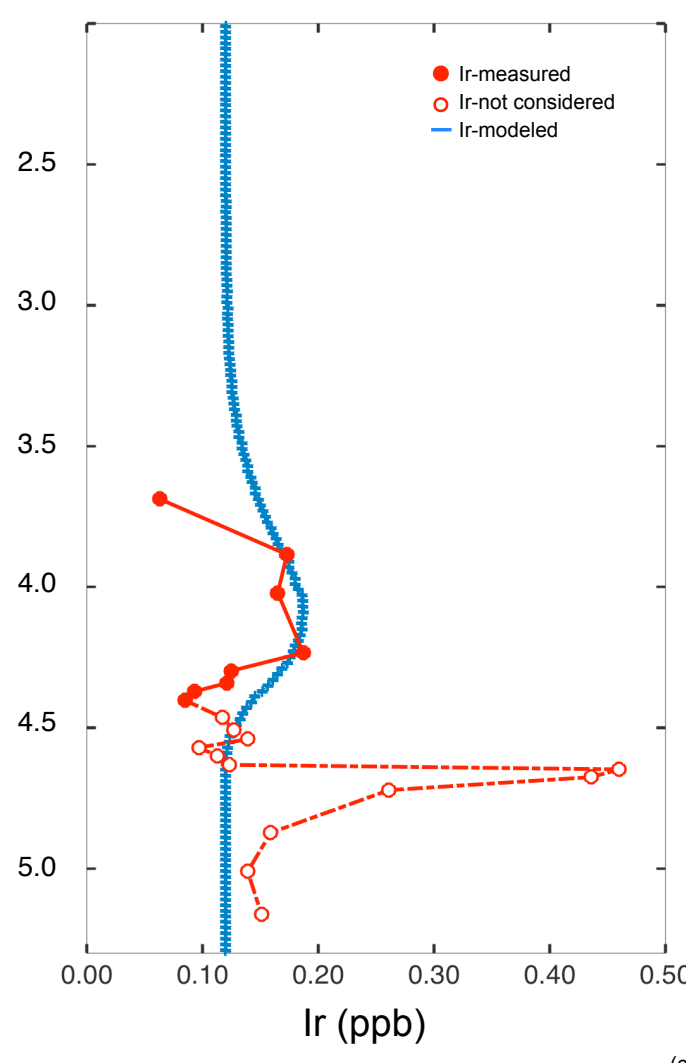

Bass River

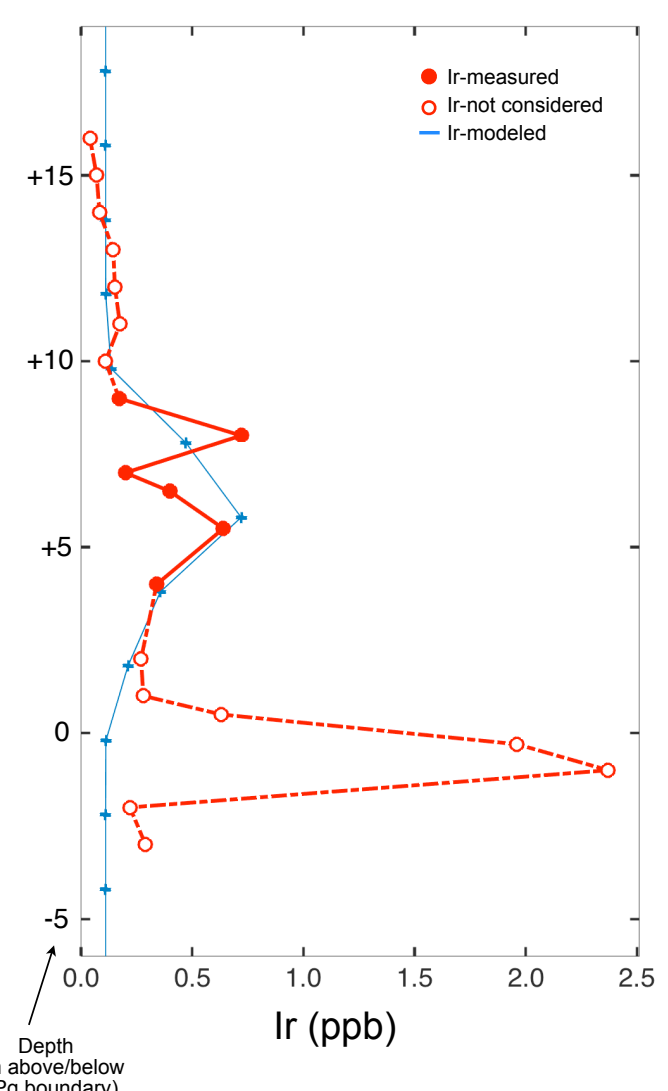




\begin{tabular}{|c|c|c|c|c|c|}
\hline Core & $\begin{array}{c}\text { maximum } \\
\text { concentration of } \\
\text { Ir-measured (ppb) }\end{array}$ & $\begin{array}{c}\text { minimum } \\
\text { concentration of } \\
\text { Ir-measured (ppb) }\end{array}$ & $\begin{array}{l}\text { thickness of the } \\
\text { Ir-enriched interval } \\
\text { (cm) }\end{array}$ & $\begin{array}{l}\text { background } \\
\text { value } \\
\text { (ppb) }\end{array}$ & $\begin{array}{l}\text { integrated Ir } \\
\text { signal } \\
\left(p p b{ }^{*} \mathrm{~m}\right)\end{array}$ \\
\hline Ancora & $0.130 \pm 0.007$ & $0.050 \pm 0.005$ & 79.25 & $0.045 \pm 0.003$ & 0.056 \\
\hline Double Trouble & $0.157 \pm 0.008$ & $0.040 \pm 0.004$ & 70.10 & $0.044 \pm 0.003$ & 0.065 \\
\hline Buck Pit 1 & $0.432 \pm 0.022$ & $0.090 \pm 0.009$ & 33.53 & $0.112 \pm 0.027$ & 0.064 \\
\hline Tighe Park 1 & $0.460 \pm 0.023$ & $0.060 \pm 0.006$ & 30.24 & $0.118 \pm 0.048$ & 0.060 \\
\hline Bass River & $2.370 \pm 0.119$ & $0.040 \pm 0.004$ & 11.00 & $0.111 \pm 0.049$ & 0.062 \\
\hline Search Farm 1 & $0.401 \pm 0.020$ & $0.020 \pm 0.002$ & 13.72 & $0.071 \pm 0.042$ & 0.019 \\
\hline Meirs Farm 1 & $0.494 \pm 0.025$ & $0.040 \pm 0.004$ & 10.67 & $0.103 \pm 0.030$ & 0.021 \\
\hline Inversand & $0.273 \pm 0.014$ & $0.030 \pm 0.002$ & 28.96 & $0.038 \pm 0.008$ & 0.025 \\
\hline
\end{tabular}

